\title{
Suicide Among Soldiers: A Review of Psychosocial Risk and Protective Factors
}

\section{Citation}

Nock, Matthew K., Charlene A. Deming, Carol S. Fullerton, Stephen E. Gilman, Matthew Goldenberg, Ronald C. Kessler, James E. McCarroll, et al. 2013. “Suicide Among Soldiers: A Review of Psychosocial Risk and Protective Factors." Psychiatry: Interpersonal and Biological Processes 76 (2) (June): 97-125. doi:10.1521/psyc.2013.76.2.97.

\section{Published Version}

doi:10.1521/psyc.2013.76.2.97

\section{Permanent link}

http://nrs.harvard.edu/urn-3:HUL.InstRepos:33459447

\section{Terms of Use}

This article was downloaded from Harvard University's DASH repository, and is made available under the terms and conditions applicable to Open Access Policy Articles, as set forth at http:// nrs.harvard.edu/urn-3:HUL.InstRepos:dash.current.terms-of-use\#OAP

\section{Share Your Story}

The Harvard community has made this article openly available.

Please share how this access benefits you. Submit a story.

\section{Accessibility}




\title{
Suicide Among Soldiers: A Review of Psychosocial Risk and Protective Factors
}

\author{
Matthew K. Nock, Charlene A. Deming, Carol S. Fullerton, Stephen E. Gilman, Matthew \\ Goldenberg, Ronald C. Kessler, James E. McCarroll, Katie A. McLaughlin, Christopher \\ Peterson, Michael Schoenbaum, Barbara Stanley, and Robert J. Ursano \\ Matthew K. Nock, Ph.D., and Charlene A. Deming, Ed.M., are affiliated with the Department of \\ Psychology, Harvard University, in Cambridge, Massachusetts. Stephen E. Gilman, Sc.D., is \\ affiliated with the Harvard School of Public Health in Boston, Massachusetts. Carol S. Fullerton, \\ Ph.D., Matthew Goldenberg, M.D., James E. McCar-roll, Ph.D., M.P.H., and Robert J. Ursano, \\ M.D., are affiliated with the Department of Psychiatry and the Center for the Study of Traumatic \\ Stress, Uniformed Services University of the Health Sciences in Bethesda, Maryland. Ronald C. \\ Kessler, Ph.D., is affiliated with the Department of Health Care Policy, Harvard Medical School, in \\ Boston, Massachusetts. Katie A. McLaughlin, Ph.D., is affiliated with Children's Hospital Boston \\ and with Harvard Medical School, in Boston, Massachusetts. Christopher Peterson, Ph.D., was \\ affiliated with the Department of Psychology, University of Michigan, in Ann Arbor, Michigan. \\ Sadly, he passed away on October 9, 2012. Michael Schoenbaum, Ph.D., is affiliated with the \\ National Institute of Mental Health in Washington, DC. Barbara Stanley, Ph.D., is affiliated with \\ Columbia University in New York, New York.
}

\section{Abstract}

Suicide is difficult to predict and prevent and remains a leading cause of death worldwide.

Although soldiers historically have had a suicide rate well below that of the general population, the suicide rate among members of the U.S. Army has increased markedly over the past several years and now exceeds that of the general population. This paper reviews psychosocial factors known to be associated with the increased risk of suicidal behavior in general and describes how some of these factors may be especially important in understanding suicide among soldiers. Moving forward, the prevention of suicide requires additional research aimed at: (a) better describing when, where, and among whom suicidal behavior occurs, (b) using exploratory studies to discover new risk and protective factors, (c) developing new methods of predicting suicidal behavior that synthesize information about modifiable risk and protective factors from multiple domains, and (d) understanding the mechanisms and pathways through which suicidal behavior develops. Although the scope and severity of this problem is daunting, the increasing attention and dedication to this issue by the Armed Forces, scientists, and society provide hope for our ability to better predict and prevent these tragic outcomes in the future.

(C) 2013 Washington School of Psychiatry

Address correspondence to Matthew K. Nock, Ph.D., Harvard University, William James Hall 1220, 33 Kirkland Street, Cambridge, MA 02138.nock@wjh.harvard.edu.

This article has been cited by:

1. Robert J. Ursano. 2013. Suicide: A National Health Challenge, An Army Health Threat. Psychiatry: Interpersonal and Biological

Processes 76:2, 95-96. [Citation] [PDF] [PDF with links] 
Since the earliest days of recorded history, societies have established military organizations in which professional soldiers are trained and expected to use physical force to defend the society against other groups. Given this mission, there is an inherent risk of injury or death associated with becoming a soldier. Historically, this risk results from participating in wars and other conflicts in which one opens oneself to injury at the hands of an outside enemy. However, evidence has recently emerged that there is also an increasing risk of self-inflicted death among soldiers.

The goals of this paper are to: (1) briefly describe the scope of the problem of suicide among military service members, (2) review what is currently known about modifiable psychosocial risk and protective factors for suicide-highlighting the factors hypothesized to be responsible for the observed increase in suicide among U.S. soldiers and most relevant for prevention efforts in the military, (3) describe potential barriers to progress in this effort, and (4) outline what we perceive to be the most promising directions for future research and prevention efforts given current knowledge of this problem.

\section{SUICIDE AMONG SOLDIERS: CURRENT SCOPE OF THE PROBLEM}

Suicide is the 16th leading cause of death worldwide and the 10th leading cause of death in the U.S. general population, accounting for approximately $1.4 \%$ of all deaths (National Vital Statistics System, 2008; World Health Organization, 2008). Until recently, the rate of suicide in the U.S. military has been well below that of the rate among civilians of the same age and sex (see Figure 1). Potential explanations for the historically lower rate among military service members are the screening out of those with significant mental health problems or a documented criminal history, the availability of a strong social network, and ready access to health care. However, beginning in 2008 the rate of suicide among soldiers in the U.S. Army has exceeded that of the adjusted general population for the first time in decades (Kuehn, 2009), a trend not observed during prior military conflicts. The current increasing trend began in 2005, shortly after the start of Operation Iraqi Freedom (OIF) (Hill, Johnson, \& Barton, 2006; Nelson, 2004) and has continued despite numerous prevention efforts by the U.S. Army (Levin, 2009). Further, in certain months and years (including the years 2010 and 2011), more soldiers died by their own hands than by those of someone else through combat (Army Human Resources, 2012; Defense Manpower Data Center, 2012a, 2012b, 2012c). It is worth mentioning that the increasing rates of suicide among Army soldiers are paralleled by increasing rates of mental disorder prevalence among this population, suggesting that perhaps suicide attempts are secondary to increasing rates of mental illness (Bachynski et al., 2012). While we might expect some people who carry vulnerability and experience extreme stressors of wartime to develop mental disorders and become suicidal, the current rate of suicide is significantly above expectations, and every effort should be made to lessen and prevent this serious behavior problem. Given the scope and seriousness of this problem, there is a desperate need to increase our understanding of the factors that may be causing this increase and how these unnecessary deaths can be prevented. As such, in this paper we focus primarily on the problem of suicide and suicidal behavior among Army soldiers. 


\section{RISK AND PROTECTIVE FACTORS FOR SUICIDE AND THEIR RELEVANCE TO SOLDIERS}

Suicidal behaviors develop through complex processes in which psychological, social, neurobiological, and demographic factors combine to place individuals at risk. When searching for risk and protective factors for suicide, it is important to keep in mind that such factors may differ according to what part of the suicidal process they predict. For both scientific and clinical purposes, it is important to distinguish between suicide ideation (i.e., serious thoughts about killing oneself), suicide plans (i.e., formulation of an actual plot to kill oneself), suicide attempts (i.e., performance of self-injurious behavior with some intent to die), and suicide death. These distinctions are important because these outcomes have different base rates, courses, and correlates (Moscicki, 1999; Nock, Borges, Bromet, Cha, et al., 2008). It also is important to distinguish between self-injury with intent to die (suicidal self-injury) and self-injury with no intent to die (non-suicidal self-injury; for more information see Nock, 2009a). Non-suicidal self-injury (NSSI) is performed most often as a way of decreasing distressing emotions (Nock, 2009b); however, it sometimes serves as a suicide gesture, in which a person leads others to believe that he has just made a suicide attempt in order to communicate that he is in distress or to influence the behavior of others in some way (Nock, 2008; Nock \& Kessler, 2006; Tucker \& Gorman, 1967). It is meaningful to note that although a suicide gesture may be a form of NSSI if any skin tissue is damaged, a suicide gesture also may lack actual self-injury altogether (e.g., displaying an empty pill bottle to give the illusion that one has consumed a large quantity of pills). Although some researchers and clinicians dislike the term "gesture," holding that it denotes that an individual intends to "manipulate" others (see Silverman, Berman, Sanddal, O'Carroll P, \& Joiner, 2007; Tucker \& Gorman, 1967), the use of the term in this paper carries no such connotation. Instead, it is utilized due to its specificity in describing the use of an action to express emotions and/or thoughts. In this section, we review evidence on risk and protective factors for both suicide death and non-fatal suicidal behaviour havior (i.e., suicide ideation, plans, and attempts), noting important differences when present among the predictors of different suicidal outcomes. Importantly, we also highlight which risk factors are expected to be of greatest potential value in helping to explain, predict, and prevent suicide among soldiers.

\section{An Organizing Conceptual Model}

A wide range of risk and protective factors influences the occurrence of suicidal behaviors, and it is difficult to understand how and why they interact. Therefore, it is useful to have a conceptual framework for organizing known risk factors and for guiding future tests of the development of suicidal behavior. Many theoretical models of suicide have been proposed in the literature, and although they differ in focus and level of analysis (e.g., biological versus environmental models), virtually all distinguish between vulnerability or distal factors that predispose some people to be at high risk for suicide (e.g., presence of mental illness, prior suicidal behavior) and stressors or proximal factors that trigger suicidal behaviors among those who are vulnerable (e.g., hopelessness, sleep issues). Given that vulnerability-stress models guide current thinking about suicidal behavior (Ingram \& Luxton, 2005; Mann, 
Waternaux, Haas, \& Malone, 1999), such a model is used here to organize the conceptualization of risk and protective factors (Figure 2).

\section{Vulnerability Factors}

Presence of Mental IIIness-The presence of a mental disorder is among the most consistently reported risk factors for suicidal behavior (Gould et al., 1998; Hyman, Ireland, Frost, \& Cottrell, 2012; Kessler, Borges, \& Walters, 1999; Mann et al., 1999; Nock, Borges, Bromet, Alonso, et al., 2008; Petronis, Samuels, Moscicki, \& Anthony, 1990; Shaffer et al., 1996). Psychological autopsy studies reveal that $90-95 \%$ of the people who die by suicide have a diagnosable mental disorder at the time of their death (Cavanagh, Carson, Sharpe, \& Lawrie, 2003), and similar (but slightly lower) rates have been found among those making non-lethal suicide attempts (Kessler, Berglund, Borges, Nock, \& Wang, 2005; Nock et al., 2009). Mood, alcohol/substance, impulse-control, psychotic, and personality disorders convey the highest risks (Hawton, Houston, Haw, Townsend, \& Harriss, 2003; Kessler et al., 1999; Linehan, Rizvi, Welch, \& Page, 2000; Mann et al., 1999; Shaffer et al., 1996; Shafii, Carrigan, Whittinghill, \& Derrick, 1985), and the accumulation of disorders (e.g., combined Axis I and Axis II disorders) is associated with especially elevated risk (Hawton et al., 2003; Kessler et al., 1999; Nock, Borges, Bromet, Alonso, et al., 2008; Shafii, SteltzLenarsky, Derrick, Beckner, \& Whittinghill, 1988). Comorbidity of mental illness represents a major challenge for suicide prevention, as comorbid disorders can be more difficult to diagnose and to treat. In addition, recent evidence suggests that different disorders predict the transition between suicide-related outcomes. For instance, although a history of major depression is one of the strongest predictors of suicide ideation, it does not predict suicide attempts among ideators. Instead, disorders characterized by anxiety/agitation (e.g., posttraumatic stress disorder [PTSD]) and problems with aggression/impulsiveness (e.g., conduct disorder, substance disorders) best predict the transition from suicide ideation to attempt (Nock, Hwang, Sampson, \& Kessler, 2010; Nock et al., 2009).

The fact that the vast majority of suicides occur among people with a current mental disorder makes this risk factor a prime target for screening and prevention efforts. One potential suicide prevention strategy would be to adopt programs aimed at preventing the first onset of mental disorder. However, given the high prevalence and early age of onset of mental disorders (Kessler, Berglund, Demler et al., 2005; Kessler, Chiu, Demler, Merikangas, \& Walters, 2005), it would seem to be more feasible in the Army context to screen for pre-existing mental disorders and to target the bulk of prevention efforts to soldiers with a pre-recruitment history of mental disorder. Caution will be needed here, though, as many soldiers are in the age range in which risk for first onset of mental disorders is high, and they therefore may become ill only after joining the Army, particularly after experiencing stressors related to war (e.g., stress of basic training, sleep deprivation, loss of family support, being away from home). Indeed, recent reports indicate that as many as $25 \%$ of U.S. military personnel returning from deployments to OIF and Operation Enduring Freedom (OEF) report psychological problems, raising the possibility of elevated suicide risk among these soldiers (Hoge, Auchterlonie, \& Milliken, 2006; Hoge et al., 2004). Ongoing screening for mental disorders and referral to treatment may be an effective method of detecting those at risk and decreasing the likelihood of suicidal behavior. For instance, in 
a study of airmen given a Post-Deployment Health Assessment directly upon returning home from deployment and a Post-Deployment Health Reassessment (PDHRA) 90-180 days thereafter, researchers found the PDHRA to be moderately effective in detecting PTSD and depression. Interestingly, this measure demonstrated low specificity such that even individuals without acute levels of distress were identified and given access to supportive services-perhaps allowing for preventive intervention (McCarthy, Thompson, \& Knox, 2012). Though screening for mental disorders is a promising avenue for reducing suicides, it is important to remember that having a mental disorder alone is not sufficient to explain or predict suicidal behavior, as the majority of people with mental disorders never engage in suicidal behavior (Nock, Borges, Bromet, Alonso et al., 2008; Nock, Borges, Bromet, Cha et al., 2008; Nock et al., 2010; Nock et al., 2009). This means that we cannot rely on the presence of a mental disorder alone to accurately predict suicidal behavior. It is important to consider other factors that may also explain the pathway to suicide.

Psychological Factors-Although mental disorders are strongly associated with suicidal behavior, it is not yet clear exactly why this is so. There is growing evidence that specific psychological factors that are not tied to any particular mental disorder are useful in beginning to better understand this association. For example, emotion reactivity has been shown to mediate the relationship between the presence of psychopathology and self-injury (both NSSI and suicide ideation), and it is likely only one of many psychological factors that do so (Nock, Wedig, Holmberg, \& Hooley, 2008).

There are two general types of psychological factors that may convey vulnerability for suicide risk. First, subjectively reported psychological factors predict suicidal behavior. These include personality traits, temperamental factors, and other cognitive-affective states, such as: impulsiveness (Fawcett, 2001; Fawcett, Busch, Jacobs, Kravitz, \& Fogg, 1997; Mann et al., 1999; Zouk, Tousignant, Seguin, Lesage, \& Turecki, 2006), aggressiveness (Conner, Swogger, \& Houston, 2009; Keilp et al., 2006; McGirr \& Turecki, 2007; Nock \& Marzuk, 2000), hopelessness about the future (Beck, Steer, Kovacs, \& Garrison, 1985; Brezo, Paris, \& Turecki, 2006; Brown, Beck, Steer, \& Grisham, 2000), and anhedonia (Fawcett et al., 1990; Nock \& Kazdin, 2002).

Second, a range of objectively measured neurocognitive factors-primarily in the domain of executive functioning - have been found in suicidal behavior, including problems with: decision-making, problem-solving, cognitive control, and verbal fluency (Jollant et al., 2005; Keilp, Gorlyn, Oquendo, Burke, \& Mann, 2008; Sadowski \& Kelley, 1993). One of the most important tasks for research on suicide is determining which of these factors, or more precisely which combination of these factors, is most predictive of suicidal behavior. Different theoretical models propose different combinations of factors, but this remains an open question. Most models suggest that suicide results from the aforementioned constructs interacting to: (a) elevate the distress a person feels in response to a negative situation (e.g., high reactivity), (b) decrease a person's ability to problem-solve or to seek help through an adaptive method (e.g., poor decision-making, problem-solving), or (c) increase a person's likelihood of acting on impulses to escape from the undesirable situation via suicide (e.g., impulsiveness, aggressiveness) (Baumeister, 1990; Keilp et al., 2006; Line-han, 1993; Mann et al., 1999). 
As with mental disorders, in the absence of evidence to the contrary it is plausible to assume that these psychological constructs are just as likely to lead to suicidal behavior among soldiers as the general population. Here, too, it is possible that either recent changes in entrance criteria could have led to recruitment of more soldiers with high levels of these psychological factors (e.g., impulsiveness, aggressiveness, poor decision-making) or that these risk factors have increased over time in response to an increasingly stressful environment. This is an important question for future studies. In either case, psychological factors are likely to prove extremely valuable for predicting and preventing suicide because these factors can be screened and, in most cases, are modifiable and thus represent promising targets for intervention. Indeed, psychological interventions focused on modifying these kinds of factors (e.g., problem-solving, distress tolerance) are among the few interventions that have demonstrated an ability to decrease the likelihood of future suicide attempts among those at risk (Brown et al., 2005; Linehan et al., 2006).

\section{Family History of Mental Disorder, Childhood Adversities, and Suicidal Behavior}

People with a family history of mental disorders and suicidal behavior are at increased risk for suicidal behavior (Brent \& Mann, 2006; Brent et al., 2002). Importantly, the associations between parental psychopathology and suicidal behavior among offspring persist even after controlling for the comorbidity of parental disorders and presence of mental disorders in the offspring (Gureje et al., 2010). This suggests that what is being transmitted crossgenerationally is a predisposition for some trait that is not fully explained by the presence of mental disorders (e.g., impulsive aggression). Parental history of panic disorder, antisocial personality disorder, and suicidal behavior has proven to be especially important in the prediction of suicidal behavior among offspring, supporting the hypothesized transmission of impulsive aggression or high emotional reactivity (Gureje et al., 2011). Unfortunately, although there have been some exciting findings relating genetic factors to suicidal behaviors that could conceivably help to better understand the transmission of suicidal behavior across generations, large-scale genome-wide association studies have failed to replicate initial findings from smaller studies (Perlis et al., 2010).

A reliable association also has been found between a history of childhood adversities (e.g., childhood sexual and physical abuse, household dysfunction) and subsequent suicidal behavior (Brodsky \& Stanley, 2008; Bruffaerts et al., 2010; Dube et al., 2001; Joiner et al., 2007; Nock \& Kessler, 2006). This association is partially mediated by the occurrence of mental disorders among those who experience such adversities (Dube et al., 2001). This link also may be explained in part by the shared genetic and neuro-biological characteristics of parent and off-spring, in which parents who are impulsive and aggressive by nature-and as a byproduct abusive to their children-are more likely to have children who are impulsive and aggressive. Both the familial transmission of sexual abuse and/or impulsive aggression have been suggested as potential mediators in the transmission of suicidal behavior (Brent et al., 2002; Brent et al., 2003). Evidence from experimental studies of non-human primates reveals that early rearing experiences, such as being raised in a deprived social environment, contribute independently to the development of impulsive, aggressive, and self-injurious behavior, with dysfunction of the neurotransmitter serotonin appearing to mediate this relationship (Higley \& Linnoila, 1997; Kraemer, Schmidt, \& Ebert, 1997), suggesting that 
childhood adversities ("neglect" in this instance) may be causally related to suicidal behaviors. Attachment styles also have been found to be strongly related to psychopathology; disorganized/controlling and insecure types may be of special importance (Agrawal, Gunderson, Holmes, \& Lyons-Ruth, 2004; Lyons-Ruth \& Jacob-vitz, 2008). For instance, insecure types (e.g., unresolved, preoccupied, fearful) have been shown to have a strong association with borderline personality disorder (Agrawal et al., 2004).

Building on both animal models of early adversities and human models focused on early child-parent interactions, a growing body of work is showing that childhood adversity is associated with the epigenetic regulation of genes that play a role in the human stress response system (e.g., McGowan et al., 2009). These alterations in the stress response system could in turn lead to problems with psychological abilities, such as emotion regulation and decision making, which could increase the likelihood of suicidal behavior (Turecki, Ernst, Jollant, Labonte, \& Mechawar, 2012).

Family history factors are of course not modifiable, but could be useful in the determination of who is at elevated risk for suicidal behavior and therefore can be targeted in screening programs. They have been shown to improve the prediction of 12-month suicide attempts in prior work, above and beyond the influence of other risk factors, such as a person's own mental disorder (Borges et al., 2006; Borges et al., 2010). The use of information about a family history of mental disorders as a way of assessing risk of suicidal behavior may prove particularly useful in the Army context as such information does not require asking about the soldier's own psychological state and thus may be less likely to be influenced by reporting bias. On balance, although family history factors can improve the prediction of suicidal behavior, these factors alone are unlikely to provide accurate prediction of suicidal outcomes.

\section{Stressful Life Experiences}

Suicidal behaviors most often are preceded by stressful life events that can be acute (e.g., family/romantic conflicts, bereavement, legal/disciplinary problems, military sexual trauma —especially among female soldiers) (Brent et al., 1993; M. R. Phillips et al., 2002; Ritchie, Keppler, \& Rothberg, 2003; Vijayakumar \& Rajkumar, 1999; Wieland, Haley, \& Bouder, 2011; Yen et al., 2005) or more chronic (e.g., chronic pain, physical illness [among physical conditions, epilepsy has been shown to be most strongly related to suicidal thoughts and behaviors]) (Braden \& Sullivan, 2008; Druss \& Pincus, 2000; Scott et al., 2010). A wide range of traumatic events are related to suicidal outcomes (with sexual and interpersonal violence showing particularly strong associations), and a dose-response relationship between the number of events and suicidal thoughts/behaviors has been observed (Stein et al., 2010). Stressful life events may play an especially strong role in the occurrence, and potentially in the recent increase, of suicide among soldiers, given the severely stressful events associated with military training and practice in general. Soldiers experience many different forms of stressors, which can be classified as: military-related stressors (e.g., combat exposure, injury, bereavement, negative unit climate—such as feeling ostracized from one's unit, not fitting in, or feeling that one has let the unit down), family-related stressors (e.g., separation from family, marital/romantic distress or infidelity, family illness/death), and other personal 
stressors (e.g., legal/disciplinary problems, physical/ sexual assault, acute health problems, financial/occupational problems). In a study of U.S. Army suicide decedents, researchers found that among the most common stress-related circumstances occurring prior to suicide death were intimate partner problems (44.6\%) and military-related stress (41.1\%). The most prevalent military stressors included current job-related problems and the experience of combat in the most recent deployment (Logan, Skopp, Karch, Reger, \& Gahm, 2012). Similarly, the research of Hyman and colleagues (2012) supports the associations between suicide among active duty members and stressors such as separation or divorce, reduction in rank, enlisted rank, and sleep prescriptions. Other research among young adults in the military finds that sleep issues predict suicide ideation and behavior even after accounting for depression and hopelessness (Ribeiro et al., 2012). Such stressors may play an important role in the occurrence of suicide among soldiers overall, and may be a major contributor to the recent increase in suicide among soldiers (Kuehn, 2009).

Additional areas of stressors that have been cited as being particularly difficult for soldiers today include the following. First, the nature of the combat exposure associated with OIF and OEF is one that can cause significant prolonged stress, requiring many of those currently deployed to be on constant guard for improvised explosive devices, enemy fire, and other dangers while patrolling civilian areas. Second, the prolonged and repeated nature of many current deployments (and accompanying re-exposures to traumatic events) along with uncertainty about whether one's tour will be extended can create significant strain on one's family relationships. Third, advances in modern medicine that have created new lifesaving interventions among those injured in combat may, paradoxically, increase the overall suicide rate via higher distress among those who survive but whose injuries have left them with serious health problems or disfigurement. Indeed, wounded soldiers in Warrior Transition Units may be at an increased risk for suicide; this remains an important area for study (Cavallaro, 2009; Dao \& Frosch, 2010).

One type of stressor (in terms of a diathesis-stress model) that may have particular relevance for suicide risk in military populations is traumatic brain injury. A substantial proportion of Army personnel deployed in Iraq and Afghanistan have experienced a traumatic brain injury (Hoge et al., 2008; Schneiderman, Braver, \& Kang, 2008). The high prevalence of such injuries among military personnel in these conflicts is a consequence of widespread exposure to improvised explosive devices and other non-fatal explosion or blast injuries that result in head trauma (Warden, 2006). Traumatic brain injury is associated with increased risk of depression and PTSD (Hoge et al., 2008; Kreutzer, Seel, \& Gourley, 2001; Schneider-man et al., 2008), and neuropsychological consequences of traumatic brain injury include impulsivity, aggression, and disinhibition (Kim, 2002; Rao \& Lyketsos, 2000). These mental health and neuropsychological sequelae of traumatic brain injury may, in turn, increase risk for suicide. Indeed, several studies have documented an increased risk of suicidal behavior among individuals with traumatic brain injury (Simpson \& Tate, 2002; Teasdale \& Engberg, 2001). These findings suggest that Army personnel who have experienced a traumatic brain injury may be at particularly elevated risk for suicide and therefore represent an important population to target with preventive interventions. 
An important direction for future work - and one that is especially important for potential interventions-is to determine how and why these stressful life experiences lead to suicidal behavior. Are these stressors only important in the presence of specific vulnerability factors? Is it the type or accumulation of stressors that is most important? Surprisingly, it is not exactly clear how and why stress actually influences the development of suicidal behavior. Stressful life events may influence suicide risk through a variety of pathways. For example, stress exposure predicts subsequent changes in a variety of psychological processes that are associated with suicidal behavior, including emotional reactivity (Wichers et al., 2009), emotion regulation (McLaughlin \& Hatzenbuehler, 2009), and hopelessness (Dixon, Rumford, Heppner, \& Lips, 1992). Certain types of stress ful life events, including interpersonal loss, are associated with heightened impulsivity in regards to suicide attempts (Weyrauch, Roy-Byrne, Katon, \& Wilson, 2001). Stressful experiences may also influence risk for suicidal behavior through neurobiological pathways. Structural consequences of exposure to early stress include: lessened development of the left neocortex, hippocampus, and amygdala; reduction in the size of the mid-portions of the corpus callosum; and alterations in the development and functioning of the prefrontal cortex (Teicher et al., 2003). Effects on the prefrontal cortex are of particular importance in the study of suicide, as alterations to the prefrontal cortex are associated with impairments in emotion regulation and executive functioning. The prefrontal cortex has a protracted developmental trajectory extending well into adolescence (Gogtay et al., 2004) and has dense concentrations of glucocorticoid receptors (Diorio, Viau, \& Meaney, 1993), both of which increase the susceptibility of the prefrontal cortex to environmental stress. The prefrontal cortex performs important control functions over reward pathways and plays a critical role in emotion regulation and decision-making (Ochsner et al., 2004; Ridderinkhof, van den Wildenberg, Segalowitz, \& Carter, 2004). Prefrontal cortex deficits are associated strongly with impulsivity and aggression (Anderson, Bechara, Damasio, Tranel, \& Damasio, 1999; Best, Williams, \& Coccaro, 2002; Davidson, Putnam, \& Larson, 2000; Grafman et al., 1996), and evidence from both animal and human studies documents that exposure to environmental stress can disrupt inhibitory control and prefrontal cortex functioning (Pollak et al., 2010; Radley et al., 2006; Williams et al., 2006). Identifying the specific psychological and neurobiological pathways through which cumulative stress might lead to suicidal behavior represents an important area for future research. Such an approach could be useful in examining the cumulative effects of combat stress (e.g., multiple deployments), traumatic brain injury and other combat-related injuries, and interpersonal stressors (e.g., divorce, marital conflict) and the biological mechanisms through which these stressors may lead to suicidal behavior.

\section{Other Key Risk Factors}

Demographic Factors-Demographic factors such as sex, race/ethnicity, and age have strong associations with suicidal behavior; however, little research has been done to determine the extent to which these associations are due to demographic differences in preexisting psychopathology. Notably, women are more likely to make suicide attempts, but men in the United States die by suicide at a rate four times higher than that of women (Nock, Borges, Bromet, Cha, et al., 2008), a difference often attributed to the use of more lethal methods (e.g., firearms), greater aggressiveness, and higher intent to die among men 
(Beautrais, 2002; Nock \& Kessler, 2006). Race/ethnicity also is strongly associated with suicide, with those identified as non-Hispanic White having a much higher rate of suicide death than other groups (Centers for Disease Control and Prevention, 2013). Among White men (who make up approximately $72 \%$ of all U.S. suicides), the rate of suicide increases markedly in late adolescence and early adulthood and remains elevated throughout the lifespan (Centers for Disease Control and Prevention, 2013). Additional demographic risk factors in the general population include being young, unmarried, unemployed, and having low education (Bertolote et al., 2005; Nock, Borges, Bromet, Alonso, et al., 2008; Platt et al., 1992). The demographic composition of the U.S. military (disproportionately young and male) in itself places soldiers at an elevated risk for suicide. Importantly, these factors also are related to diminished help-seeking behavior (Wang et al., 2005). Although not modifiable, demographic factors are important because they may serve as moderators of other risk factors that can be altered. For example, increasing support networks within the service may be helpful for those who are unmarried but not necessarily for those married with children. Thus, such factors should be borne in mind when developing, implementing, and evaluating prevention efforts.

Prior Suicidal Behavior-A history of suicidal behavior is the strongest predictor of future suicide attempts (Christiansen \& Jensen, 2007; Nock, Borges, Bromet, Cha, et al., 2008) and suicide (Beautrais, 2001; Oquendo et al., 2004). Although not modifiable, knowledge of prior suicidal behavior can be valuable in determining who is most at risk for such behavior in the future. People who have made a previous suicide attempt are approximately 40 times more likely to eventually die by suicide than those without such a history (Harris \& Barraclough, 1997), and the association between past attempts and current suicidal behavior remains significant even when a host of other well-established risk factors for suicidal acts are controlled (Joiner et al., 2005). Multiple suicide attempts, in particular, are associated with an increased risk of subsequent suicidal behavior (Oquendo et al., 2007), and those who make multiple attempts often do so with increasing severity (Carter, Reith, Whyte, \& McPherson, 2005). Similarly, NSSI, such as superficial cutting, burning, and selfhitting, is associated with an increased risk for suicidal behavior (Dulit, Fyer, Leon, Brodsky, \& Frances, 1994; Nock, Joiner, Gordon, Lloyd-Richardson, \& Prinstein, 2006; Prinstein et al., 2008). In fact, a history of NSSI may be an even stronger predictor of suicide attempts than a history of previous attempts as shown by 28- and 24-week follow-ups in the Adolescent Depression Antidepressants and Psychotherapy Trial (ADAPT) and the Treatment of Selective Serotonin Reuptake Inhibitors-Resistant Depression in Adolescents (TORDIA) studies, respectively (Asarnow et al., 2011; Wilkinson, Kelvin, Roberts, Dubicka, \& Goodyer, 2011). These findings emphasize the potential importance of assessing and treating NSSI in the prevention of suicide attempts.

Situational Factors-Situational factors, such as having ready access to lethal means, predict suicidal behavior. Army personnel have access to and experience with firearms, which increases suicide risk (firearms are used in more suicides than homicides each year in the U.S.) (Miller \& Hemenway, 2008). Obtaining a personal firearm upon return home from deployment may represent a warning sign that could be an intervention target among soldiers (Rudd et al., 2006). Although a fairly focused and concrete factor, taking steps to 
improve gun safety may be an important and easily implemented intervention strategy. In support of this suggestion, suicide among soldiers in the Israeli Army decreased by $40 \%$ following reforms in 2006 that decreased soldiers' access to firearms on weekends (Rosenbaum, 2012). Other forms of means restriction (e.g., reduced access to alcohol) also have been associated with reductions in suicide (Mann et al., 2005). The identification of additional Army-specific situational factors could guide future efforts already in place such as Unit Watch (aka Command Interest Profile), a procedure implemented at the recommendation of a clinician and carried out by a soldier's command team that can include a number of interventions, such as limiting access to dangerous items (Payne, Hill, \& Johnson, 2008).

\section{Protective Factors}

Whereas risk factors increase the likelihood of suicidal behaviors, protective factors decrease their probability among those at elevated risk (i.e., among those with known risk factors). Protective factors for suicide have been less frequently examined than risk factors, and perhaps because of this lack of empirical support, they are viewed with skepticism by some researchers and clinicians. However, a number of studies in this area have reported encouraging results.

Social Support-Most protective factors tested to date have involved facets of social or familial support. For instance, religious affiliation (Dervic et al., 2004), responsibility to one's family (Oquendo et al., 2005), and being pregnant or having children in the home are all protective against suicidal behavior (Marzuk et al., 1997; Qin \& Mortensen, 2003). These all are relevant to soldiers, as are other forms of social support, including that from one's unit (e.g., unit cohesion/ climate), family (e.g., frequency of contact with spouse), and friends (e.g., use of social networks). The experience of social support within one's unit may be an especially important protective factor. Prior research on unit cohesion has shown that a soldier's perception of supportive leadership and strong peer (i.e., soldier-to-soldier) relations lessens the likelihood of leaving the Army and enhances perceptions of combat readiness (Griffith, 2002; Halverson, Bliese, Moore, \& Castro, 1995). More important, unit cohesion can buffer against the deleterious effects of stress, the development of PTSD and other psychiatric symptoms, and potentially against the occurrence of suicidal behavior (Brailey, Vasterling, Proctor, Constans, \& Friedman, 2007; Halverson et al., 1995).

Psychological Protective Factors-There has been an enormous increase in the past decade in research on psychological factors that may protect against negative outcomes. Work in this area typically is referred to as "positive psychology" given its focus on the development of favorable outcomes, and it has yielded a wide array of constructs and measures that may significantly advance the understanding of why some people respond adaptively to stressful events. Such constructs include resilience, stoicism, character strength, life satisfaction, positive moods, self-esteem, autonomy, hope (optimism), zest, gratitude, capacity to love (ability to form reciprocated relationships), and a sense of meaning and purpose. Recently, there has been a surge of interest in the construct of resilience (South-wick, Litz, Charney, \& Friedman, 2012). The study of resilience is complicated by a number of factors, perhaps the most fundamental of which is a lack of 
agreement on the definition of this term. Bonanno (2012, p. 755) has described resilience as "a stable pattern of healthy adjustment" following an aversive event. Similarly, the American Psychological Association (2010) has defined this construct as "the process of adapting well in the face of adversity, trauma, tragedy, threats or even significant sources of stress." In seeking to understand resilience, researchers have emphasized a number of points, including: (a) resilience is distinct from recovery, (b) resilience can be common, and (c) there are many different pathways to resilience (e.g., hardiness, self-enhancement, repressive coping, positive emotion and laughter) (Bonanno, 2004). In a recent review of resilience and suicidal thoughts and behaviors, researchers identified consistent buffering effects for overall positivity of attributional style and high levels of agency (Johnson, Wood, Gooding, Taylor, \& Tarrier, 2011).

Research in positive psychology has demonstrated that the presence of specific characteristics-for example, positive reinterpretation and acceptance coping as well as intrinsic religiousness (Park, Cohen, \& Murch, 1996) — can promote adaptive functioning following extreme stress (i.e., post-traumatic growth; PTG) (Linley \& Joseph, 2004; Peterson, Park, Pole, D'Andrea, \& Seligman, 2008). Among a group of service members with combat or war zone experience, greater PTG has been associated with lesser suicide ideation (Bush, Skopp, Mc-Cann, \& Luxton, 2011). Other studies have found that the association between stressful life events and subsequent suicide attempt is virtually eliminated among those high on factors such as emotional intelligence (i.e., the ability to perceive, understand, and manage one's emotions) (Cha \& Nock, 2009). These factors may help to explain why some soldiers exposed to extreme stress adapt fairly well, while others do not. An important point to keep in mind is that some characteristics (e.g., stoicism, autonomy) that are encouraged in military training and culture are likely to work well in improving soldiers' functioning in most situations, but paradoxically may decrease the likelihood that a soldier seeks help for a mental disorder or other problem they are having difficulty managing.

Importantly, brief interventions designed to enhance some of these constructs have shown an ability to decrease depressive symptoms (Fava et al., 2004; Seligman, Steen, Park, \& Peterson, 2005), suggesting that some positive psychology-related constructs are modifiable and can be used in new prevention and intervention efforts. Such interventions are currently being tested in the military as part of a large-scale research study called Comprehensive Soldier Fitness, which "represents the Army's decision to place the same emphasis on psychological, emotional and mental strength that we give to physical strength" (Army Posture Statement, 2012, p.1; Seligman \& Fowler, 2011).

There are special challenges to causal inference as it relates to the study of suicide. For ethical reasons, suicide researchers cannot experimentally increase the risk of suicidal thoughts and behaviors. Therefore, intervention studies are of particular importance in determining causal risk factors (i.e., a risk factor that can be manipulated and when manipulated can alter the risk of the outcome) for suicide.

Mental Health Treatment-One concrete strategy for attempting to decrease the rate of suicidal behaviors and maintain soldier functioning is to better understand mental health 
service use among soldiers. Factors that may prove important in this regard are the type and adequacy of treatment provided to those at risk, the probability and speed of entering treatment, and the barriers to receiving and remaining in treatment (Hoge et al., 2004; Wang, Aguilar-Gaxiola, et al., 2007; Wang, Angermeyer, et al., 2007; Wang et al., 2005). A broad range of barriers may influence treatment, including structural factors (e.g., financial barriers, unavailability of services) and perceptual factors (e.g., perceived stigma, perceived ineffectiveness of treatment, low perceived need, desire to handle the problem alone) (Bruffaerts et al., 2011; Kaskutas, Weisner, \& Caetano, 1997; Wang et al., 2008). Importantly, the assessment of perceived stigma related to the receipt of services for mental health problems, as well as the assessment of other potential barriers, should be considered among soldiers, squad leaders, and family members (Hoge et al., 2004; King et al., 2007). Physical health and fitness also may serve a protective function among those at risk, serving as methods of "self-treatment," such as regular aerobic exercise and consumption of vitamins. Experiments testing the effects of aerobic exercise have shown that exercise is associated with moderate decreases in depressive symptoms, with effects similar to those seen in cognitive therapy (Mead et al., 2008). Given the stigma and other barriers to access often associated with seeking traditional mental health treatment, alternative prevention models should be given special consideration, such as peer support, improved handling of suicidal crises by unit command, media, and phone/Internet-based interventions.

There have been relatively few randomized controlled trials (RCTs) of treatments targeting suicidal thoughts and behaviors. Of the existing RCTs, only a handful has been shown to significantly reduce target thoughts and behaviors. Here, we briefly discuss three psychological treatments that have shown promising results. A first option, Dialectical Behavior Therapy (DBT), is the treatment with the most empirical support for the reduction of suicidal thoughts and behaviors (Linehan, 1993). DBT was developed to treat those with chronic suicidal thoughts and behaviors and is a comprehensive cognitive-behavioral therapy that includes principles of Zen and contemplative practices along with learning and crises theory, highly structured components for each aspect of therapy (e.g., group/ individual skills training, individual therapy, phone contact with therapist), and a focus on maintaining motivation among therapists (Dimeff $\&$ Linehan, 2001), There are a number of RCTs demonstrating the usefulness of DBT in de creasing the risk of suicide re-attempt among adult attempters (e.g., Linehan, Armstrong, Suarez, Allmon, \& Heard, 1991; Verheul et al., 2003), including a study conducted among female veterans meeting criteria for borderline personality disorder. Veterans receiving DBT showed significantly greater decreases in suicide ideation when compared to those receiving treatment as usual (Koons et al., 2001). A second treatment option, Cognitive Therapy (CT), views suicide attempts as dysfunctional coping strategies for dealing with feelings of severe distress (GhahramanlouHolloway, Brown, \& Beck, 2008). A primary aim of CT, therefore, is to enhance problemsolving skills, ensuring that suicide is not the only option for distressed individuals (Ghahramanlou-Holloway, Bhar, Brown, Olsen, \& Beck, 2012). CT has been shown to be efficacious in treating those who have made prior suicide attempts, with a 50\% reduction in the recurrence of re-attempt (Brown et al., 2005). A third option for treatment is Collaborative Assessment and Management of Suicidality (CAMS) (Jobes, 2000, 2006). CAMS is an organized method for assessing and managing suicide, emphasizing 
collaboration between the clinician and patient. This approach highlights the patient's own phenomenological perspectives, thereby aiming to reach an accurate assessment and simultaneously strengthening the therapeutic alliance (Ellis, 2004; Ellis, Allen, Woodson, Frueh, \& Jobes, 2009). CAMS has been shown to reduce suicide ideation more quickly and effectively than treatment as usual (Jobes, Wong, Conrad, Drozd, \& Neal-Walden, 2005).

\section{MAJOR CHALLENGES FOR RESEARCH AND PREVENTION}

Suicide has remained a leading cause of death-with the same rate in the United States today as it was 100 years ago (Goldsmith, Pellmar, Kleinman, \& Bunney, 2002; Nock, Borges, Bromet, Cha, et al., 2008) — due to several major challenges that make it an especially difficult behavior to study. First, suicidal behavior occurs at a fairly low baserate. This means that large samples of people are needed to have a sufficient number of cases to study the behavior in a detailed manner. Unfortunately, most prior studies have used relatively small selective samples (e.g., psychiatric inpatients), and so some of even the most basic characteristics of suicidal behavior are not well known. Second, suicidal behavior often occurs without warning. Recent research indicates that most people who experience suicidal thoughts have them for the first time by their early twenties (Nock, Borges, Bromet, Alonso, et al., 2008); however, even with this information it remains very difficult to predict which people will develop such thoughts and exactly when they will occur. Importantly, once such thoughts occur, people often transition quickly to making suicide attempts, suggesting the need for rapid action when such thoughts are detected. Indeed, more than $60 \%$ of new-onset suicide attempts occur within the first year after initial onset of suicidal thoughts (Nock, Borges, Bromet, Alonso, et al., 2008). Third, because of the relatively small sample sizes used in prior studies, researchers have been unable to conduct tests of the complex models that are needed to predict suicidal behavior. Most studies have examined the effects of individual risk factors (e.g., presence of a mental disorder) on single outcomes (e.g., presence of a suicide attempt), and have not had the statistical power or multiple measurements needed to carefully examine how risk and protective factors interact to produce suicidal behavior.

Fourth, there are major barriers to studying suicidal thoughts and behaviors using current assessment methods. In studying cases of suicide death, because the person is no longer able to provide a report on risk and protective factors, researchers must try to piece together information about risk factors via the use of psychological autopsy methods (Cavanagh et al., 2003). In study ing cases of non-lethal suicidal behavior, although people are alive for study, they often are unable or unwilling to accurately report on the factors leading up to their suicidal behavior. Prior research has shown consistently that people often are unable to accurately report on the factors influencing their behavior (Nisbett \& Wilson, 1977), and this surely extends to the case of suicidal behavior. The use of more objective assessment methods would help to circumvent problems associated with relying on self-report; however, this becomes practically difficult considering the very large sample sizes that are needed in the study of suicide, as mentioned above. Moreover, many people are unwilling to report not only on the factors leading to their behavior - such as the presence of a mental disorder-but on the presence of suicidal behavior at all. People may fail to report on suicidal thoughts or behaviors because they do not believe they have a problem, they do not 
believe there is anything or anyone that can help them, they do not want to receive any intervention, or they fear the response that others will have to learning about their suicidal thoughts and/or behaviors (Hoge et al., 2004). This last point may be particularly important among soldiers who may be dissuaded from disclosing such information for fear of having their military career hindered or discontinued. This may be especially true during a time of war when there is an expectation that each soldier will continue to perform his or her duties or risk "letting down" the other members of their unit, family, and country. Such concerns can create very real barriers that prevent those at risk from seeking help or even from reporting on their problems in screening or other assessment programs. These are only some of the many challenges facing those working to advance the understanding, prediction, and prevention of suicide. Although daunting, there remains much that can and must be done to reverse the current trend and to decrease the loss of life resulting from this devastating problem.

\section{Key Directions for Future Research}

Given what we know about the risk and protective factors for suicide in general, and among soldiers in particular, and taking into account the major challenges inherent to this area, how do we proceed? What is the best path to understanding this problem and reversing its course? We briefly outline a handful of potential hypotheses about the reason for the increasing suicide rate and then focus on describing several key directions for future research on this problem and propose that progress is needed on each if we are truly to understand and ameliorate the problem of suicide among soldiers (Table 1).

Potential Hypotheses. With an understanding of general risk factors for suicidal behaviors, as well as some more specific military factors, we now highlight potential hypotheses for why there is an increase in suicide among Army soldiers at this point in time. The following is a non-exhaustive list of possibilities. A first hypothesis is that the recent increase in military suicides is due to an increase in the rates of mental disorders among soldiersperhaps because stressors have increased the development of mental disorders in those with a vulnerability for such outcomes or because there has been an increase in the admission to the military of those with a vulnerability for a mental disorder. Increased vulnerability is possible via increases in waivers granted to entrants with a felony conviction (Alvarez, 2008), which may bring with it an increase in the percentage of soldiers with a predisposition for aggressive or antisocial behavior - traits associated with disorders that convey a high risk for suicide (Harris \& Barraclough, 1997; Nock et al., 2010; Nock et al., 2009). A second hypothesis is that the rate of suicide is increasing as stories of suicidal soldiers pervade the media, a phenomenon known as the Werther Effect (Phillips, 1974). The style and content of suicide reporting (e.g., inclusion of a description of the suicide method) have been presumed to affect the magnitude of influence (Gould, 2001; Sonneck, Etzersdorfer, \& Nagel-Kuess, 1994). Therefore, in an effort to promote appropriate dissemination of information regarding suicide completions and to decrease the social contagion effect, a number of agencies have compiled guidelines for the media (e.g., Suicide Prevention Resource Center [SPRC], 2007). In further support of this hypothesis, researchers have recently found that among civilian and military newspaper articles on suicide, $99 \%$ of reviewed reports failed to comply with at least one guideline from the SPRC 
(Edwards-Stewart, Kinn, June, \& Fullerton, 2011). Further examination of military suicide reporting and its effects is needed. A third hypothesis is that the rate of suicide has increased among soldiers as the nature of being in the military has changed and Army structural and cultural shifts have occurred. Recent structural shifts began to take place in 2006 with the Army Force Generation (ARFORGEN) initiative, which reshapes Army formations into modular units that can be deployed more quickly and can be realigned to fit specific mission requirements (Army Posture Statement, 2010; Kenyon, 2006). The effects of this and other structural/cultural shifts deserve attention.

\section{Description}

In order to understand the nature of this problem, it is vital that we first have a comprehensive descriptive picture of suicidal thoughts and behaviors. That is, who experiences suicidal thoughts and behaviors? When do they typically begin? How and at what point do they change over time? In addition to the epidemiologic research required to answer these questions, there is a need for qualitative research aimed at better understanding the factors that lead to suicide among soldiers, and to what extent suicide among members of the military may be qualitatively different from or the same as suicide among civilians. The answers to these and other descriptive questions are essential to guiding subsequent explanatory questions about why people become suicidal. For instance, if it is learned that the risk of suicide increases immediately before deployment or shortly after one returns home from deployment, this not only suggests time periods that should be targeted by screening and prevention efforts, but points toward several potentially modifiable risk factors (e.g., concerns about leaving home and entering combat, difficulties functioning post-deployment).

Prediction-Despite decades of research, scientists and clinicians still lack the ability to accurately predict suicidal behavior. Improving the ability to predict suicidal behavior before it occurs is the primary objective of work in this area. Success in this area will depend not on identifying some magical single variable that reliably leads to suicide, but on delineating what set of factors interact to increase the risk of suicide to a point that requires intervention. Several key challenges here include: identifying a set of risk factors with high sensitivity and specificity, devising a method of feasibly screening for risk over time, and determining what type of intervention is required at each level of risk. Each of these challenges requires significant attention. Consider a concrete example. One recent study revealed that approximately $30 \%$ of deployed soldiers seen for a mental health evaluation reported suicidal thoughts in the past month, and 15\% reported homicidal thoughts (Hill et al., 2006). Thoughts of suicide and homicide are significant risk factors for the associated behaviors; however, once these thoughts are identified, how should they be monitored over time? What is the appropriate intervention? At what point is the soldier fully cleared for duty? How should that person be followed over time? Questions such as these confound mental health professionals in civilian environments, but represent even greater challenges for those in deployed contexts where mental health resources are limited and demands of maintaining the force are high. Future efforts must focus on providing methods of increasing prediction accuracy that can be feasibly used in multiple military contexts (e.g., basic training, pre-deployment, in theater, post-deployment, post-active duty). 
One of the most important goals for future research on the prediction of suicidal behavior is the identification of modifiable risk factors. Non-modifiable risk factors (i.e., "risk markers") can certainly be useful for the prediction of who is at risk, but they are of limited value in intervention or prevention efforts. By contrast, the factors that predict suicidal behavior and can be changed via some form of intervention can be targeted experimentally in order to develop prevention programs for suicidal behavior. For instance, it is known that combat exposure is associated with a significant increase in mental disorders such as PTSD (Hoge et al., 2004) and that PTSD is modifiable (Adshead, 2000). Just as the military takes steps to reduce the physical harms of combat (e.g., through the use of body armor), it also could take steps to reduce the mental impact of combat (e.g., through intervening on many of the factors reviewed, both structural [number of repeated deployments] and psychosocial [maintaining unit cohesion]). When military planners attempt to calculate the risks and benefits of war in terms of human costs, the mental health impact of war should be part of the calculation.

Protection-The vast majority of research on suicide has focused on the identification of factors that increase the risk of this behavior. In contrast, we know very little about the factors that decrease the likelihood of suicidal behavior among those exposed to known risk factors. There has been an increasing effort to better understand protective factors for suicide, as mentioned in the prior section, and the continuation of this effort represents one of the most important directions for future research on suicide. As with risk factors, protective factors that are modifiable are of special importance, as they can be used to better protect soldiers from future suicide risk before any such behavior has the chance to emerge.

Prevention efforts aimed at protecting soldiers from suicide risk are currently underway. An early example of this is the Air Force Suicide Prevention Program (AFSPP). The AFSPP is a multilayered program emphasizing community and leadership involvement in the early detection and treatment of individuals at risk for suicide. Since its implementation in 1997, suicide rates in the U.S. Air Force have been significantly lower each year with the exception of 2004 (authors determined that the AFSPP program was implemented with less rigor for this year) (Knox, Litts, Talcott, Feig, \& Caine, 2003; Knox et al., 2010). More recent prevention efforts include the Suicide Assessment and Follow-up Engagement: Veteran Emergency Treatment (SAFE VET), an intervention seeking to enhance the care of suicidal veterans in VA emergency departments and to provide follow-up by telephone during the transition to outpatient care. SAFE VET consists of two components: (1) a brief psychotherapeutic intervention based on principles of the Safety Planning Intervention (Stanley \& Brown, 2012), with aspects from existing evidence-based suicide reduction strategies, including: (a) implementation of means restriction, (b) use of coping skills and problem-solving, (c) improvement of social support and understanding of who to call in an emergency, and (d) motivational enhancement for additional treatment; and (2) structured telephone contacts that include three components: (a) risk assessment, (b) review and revision of the safety plan, and (c) facilitation of engagement with outpatient care (Knox et al., 2012). Initial findings related to acceptability and feasibility of the intervention are promising, and further evaluation of the SAFE VET intervention versus enhanced usual care is currently underway. An additional effort, representing the first time in history that 
evidence-based PTSD treatment has been examined among active duty soldiers, is the South Texas Research Organizational Network Guiding Studies on Trauma and Resilience (STRONG STAR). STRONG STAR is a multi-institutional research consortium that aims to create and evaluate effective programs for the identification, prevention, and treatment of combat-related PTSD. There currently are 14 studies underway through STRONG STAR, including treatment studies, biological studies, epidemiological studies, and preclinical research (STRONG STAR, 2012). These prevention programs emphasize the need for and potential effectiveness of multi-faceted, evidence-based prevention programs.

Exploration-Many risk factors for suicidal behavior are already known, and the focus of future research is to understand how they work together to produce suicidal behavior. However, given the inability to accurately predict suicidal behavior using known risk factors, it is likely that many as yet unknown factors also hold value in predicting these outcomes. As such, there is a strong need for efforts aimed at revealing novel risk factors for suicidal behavior. Some such factors may be included and tested in new studies based on current theories of suicidal behavior or clinical observations that have not yet undergone empirical examination. Others may emerge from exploratory or data mining analyses conducted on existing databases and through the use of qualitative approaches. Especially in the case of the latter, it is important that evidence of novel risk factors be replicated to ensure that such findings are not merely due to chance. This direction has the potential to lead to the identification of new risk factors and to new ways of conceptualizing and assessing suicide risk.

Understanding-Although many risk factors for suicide currently are known, the field lacks a firm understanding of how or why most of them predict this outcome. Understanding how and why factors work together to produce an outcome is important not only for academic purposes, but for illuminating the process through which the outcome develops, which is likely to uncover potentially modifiable risk factors. For instance, more than $90 \%$ of suicides in the United States are performed by White people and approximately $80 \%$ are performed by men, yet it is not known why this is so. Additionally, mental disorders are widely known to be one of the strongest predictors of suicide, but we do not have an understanding of why this is so.

There is a great need for theoretical models that incorporate and explain the diverse range of risk and protective factors for suicide. New studies of suicide can best advance the understanding of this behavior by carefully specifying and testing the nature of the relation between the risk factors identified. Key questions that should be considered in future studies include: Is the identified factor a vulnerability (i.e., trait) or stress (i.e., state) factor? What part of the pathway to suicide does it predict (e.g., suicide ideation, plan, attempt)? Is it modifiable? What mediates and moderates its association with the suicidal outcome? Addressing these questions will require much larger sample sizes and more complex analyses than most prior studies of suicidal behavior (e.g., tests of interactions of vulnerability and stress factors; tests of prediction for different parts of the pathway to suicide), but the results of such analyses are likely to provide significant advances in our understanding of why soldiers are killing themselves at such a high rate. 


\section{CONCLUSIONS}

Suicide is an enormous public health problem in the general population, and in recent years has become an increasingly concerning problem among soldiers, with the suicide rate in the U.S. Army surpassing that for the general population for the first time in decades. Suicide is notoriously difficult to detect, predict, and prevent due to a multitude of factors, such as its low base-rate, associated stigma, and motivation to conceal suicidal thoughts or behaviors among those who have them. Each of these problems is likely to be especially at play among members in the military. Despite the daunting nature of this problem, there is reason to be optimistic. As reviewed above, significant progress has been made in recent years toward understanding risk and protective factors for suicidal behavior, conceptualizing how they may work together to produce these outcomes, and developing methods of overcoming some of the major obstacles that have faced scientific and clinical efforts in this area.

Future progress toward understanding and preventing suicide will be significantly accelerated as a result of the increased attention and resources that have been dedicated to this problem. One example of such efforts is the Army Study to Assess Risk and Resilience in Servicemembers (Army STARRS). This project was developed through a partnership between the U.S. Army and the National Institute of Mental Health and is aimed specifically at identifying modifiable risk and protective factors for suicide among soldiers. The results of this study are expected to markedly advance our understanding of why soldiers kill themselves and in doing so to provide information about how these deaths can be prevented in the future.

\section{Acknowledgments}

Army STARRS was sponsored by the Department of the Army and funded under cooperative agreement number U01MH087981 with the U.S. Department of Health and Human Services, National Institutes of Health, National Institute of Mental Health (NIH/NIMH). The contents are solely the responsibility of the authors and do not necessarily represent the views of the Department of Health and Human Services, NIMH, the Department of the Army, or the Department of Defense.

\section{REFERENCES}

Adshead G. Psychological therapies for post-traumatic stress disorder. British Journal of Psychiatry. 2000; 177:144-148. [PubMed: 11026954]

Agrawal HR, Gunderson J, Holmes BM, Lyons-Ruth K. Attachment studies with borderline patients: A review. Harvard Review of Psychiatry. 2004; 12(2):94-104. doi:10.1080/10673220490447218. [PubMed: 15204804]

Alvarez, L. Army and Marine Corps grant more felony waivers. New York Times; Apr 22. 2008 http:// www.nytimes.com/2008/04/22/washington/22waiver.html? _r=3\&ex=1366603200\&en=d4889ad7f8406a80\&ei=5088\&partner=rssnyt\&emc=rss\&oref=slogin

American Psychological Association. The road to resilience. American Psychological Association; Washington, DC: 2010.

Anderson SW, Bechara A, Damasio H, Tranel D, Damasio AR. Impairment of social and moral behavior related to early damage in human prefrontal cortext. Nature Neuroscience. 1999; 2(11): 1032-1037.

Army Human Resources. Internal, unpublished Army Report of Suicide Statistics. 2012

Army Posture Statement. 2010 Army Posture Statement, Addendum F, Army Force Generation (ARFORGEN). 2010. https://secureweb2.hqda.pentagon.mil/vdas_armyposturestatement/2010/ addenda/Addendum_F-Army\%20Force\%20Generation\%20\%28ARFORGEN\%29.asp 
Army Posture Statement. 2012 Army Posture Statement, Addendum O-Comprehensive Solder Fitness. 2012. https://secureweb2.hqda.pentagon.mil/vdas_armyposturestatement/2012/addenda/ addenda_o.apsx

Asarnow JR, Porta G, Spirito A, Emslie G, Clarke G, Wagner KD, Brent DA. Suicide attempts and nonsuicidal self-injury in the treatment of resistant depression in adolescents: Findings from the TORDIA study. [Randomized Controlled Trial Research Support, NIH, Extramural]. Journal of the American Academy of Child \& Adolescent Psychiatry. 2011; 50(8):772-781. doi:10.1016/j.jaac. 2011.04.003. [PubMed: 21784297]

Bachynski KE, Canham-Chervak M, Black SA, Dada EO, Millikan AM, Jones BH. Mental health risk factors for suicides in the US Army. Injury Prevention. 20122007-2008 doi:10.1136/ injuryprev-2011-040112.

Baumeister RF. Suicide as escape from self. Psychological Review. 1990; 97(1):90-113. [PubMed: 2408091]

Beautrais AL. Suicides and serious suicide attempts: Two populations or one? Psychological Medicine. 2001; 31(5):837-845. [PubMed: 11459381]

Beautrais AL. Gender issues in youth suicidal behaviour. Emergency Medicine (Fremantle). 2002; 14(1):35-42.

Beck AT, Steer RA, Kovacs M, Garrison B. Hopelessness and eventual suicide: A 10-year prospective study of patients hospitalized with suicidal ideation. American Journal of Psychiatry. 1985; 142(5):559-563. [PubMed: 3985195]

Bertolote JM, Fleischmann A, De Leo D, Bolhari J, Botega N, D, D. E. S. Wasserman D. Suicide attempts, plans, and ideation in culturally diverse sites: The WHO SUPREMISS community survey. Psychological Medicine. 2005; 35(10):1457-1465. [PubMed: 16164769]

Best M, Williams JM, Coccaro EF. Evidence for a dysfunctional prefrontal circuit in patients with an impulsive aggressive disorder. Proceedings of the National Academy of Science. 2002; 99(12): 8448-8453. doi:10.1073/pnas.112604099.

Bonanno GA. Loss, trauma, and human resilience: Have we underestimated the human capacity to thrive after extremely aversive events? American Psychologist. 2004; 59(1):20-28. doi: 10.1037/0003-066X.59.1.20. [PubMed: 14736317]

Bonanno GA. Uses and abuses of the resilience construct: Loss, trauma, and health-related adversities. Social Science \& Medicine. 2012; 74(5):753-756. doi:10.1016/j.socscimed.2011.11.022. [PubMed: 22300714]

Borges G, Angst J, Nock MK, Ruscio AM, Walters EE, Kessler RC. A risk index for 12-month suicide attempts in the National Comorbidity Survey Replication (NCS-R). Psychological Medicine. 2006; 36(12):1747-1757. [PubMed: 16938149]

Borges G, Nock MK, Haro JM, Hwang I, Sampson N, Alonso J, Kessler RC. Twelve-month prevalence of and risk factors for suicide attempts in the WHO World Mental Health Surveys. Journal of Clinical Psychiatry. 2010; 71(12):1617-1628. [PubMed: 20816034]

Braden JB, Sullivan MD. Suicidal thoughts and behavior among adults with self-reported pain conditions in the National Comorbidity Survey replication. Journal of Pain. 2008; 9(12):11061115. [PubMed: 19038772]

Brailey K, Vasterling JJ, Proctor SP, Constans JI, Friedman MJ. PTSD symptoms, life events, and unit cohesion in U.S. soldiers: Baseline findings from the neurocognition deployment health study. Journal of Traumatic Stress. 2007; 20(4):495-503. [PubMed: 17721953]

Brent DA, Mann JJ. Familial pathways to suicidal behavior-Understanding and preventing suicide among adolescents. New England Journal of Medicine. 2006; 355(26):2719-2721. [PubMed: 17192535]

Brent DA, Oquendo M, Birmaher B, Greenhill L, Kolko D, Stanley B, Mann JJ. Familial pathways to early-onset suicide attempt: Risk for suicidal behavior in offspring of mood-disordered suicide attempters. Archives of General Psychiatry. 2002; 59(9):801-807. [PubMed: 12215079]

Brent DA, Oquendo M, Birmaher B, Greenhill L, Kolko D, Stanley B, Mann JJ. Peripubertal suicide attempts in offspring of suicide attempters with siblings concordant for suicidal behavior. American Journal of Psychiatry. 2003; 160(8):1486-1493. [PubMed: 12900312] 
Brent DA, Perper JA, Moritz G, Baugher M, Roth C, Balach L, Schweers J. Stressful life events, psychopathology, and adolescent suicide: A case control study. Suicide and Life-Threatening Behavior. 1993; 23(3):179-187. [PubMed: 8249030]

Brezo J, Paris J, Turecki G. Personality traits as correlates of suicidal ideation, suicide attempts, and suicide completions: A systematic review. Acta Psychiatrica Scandinavica. 2006; 113(3):180-206. [PubMed: 16466403]

Brodsky BS, Stanley B. Adverse childhood experiences and suicidal behavior. Psychiatric Clinics of North America. 2008; 31(2):223-235. [PubMed: 18439446]

Brown GK, Beck AT, Steer RA, Grisham JR. Risk factors for suicide in psychiatric outpatients: A 20year prospective study. Journal of Consulting and Clinical Psychology. 2000; 68(3):371-377. [PubMed: 10883553]

Brown GK, Ten Have T, Henriques GR, Xie SX, Hollander JE, Beck AT. Cognitive therapy for the prevention of suicide attempts: A randomized controlled trial. Journal of the American Medical Association. 2005; 294(5):563-570. [PubMed: 16077050]

Bruffaerts R, Demyttenaere K, Borges G, Haro JM, Chiu WT, Hwang I, Nock MK. Childhood adversities as risk factors for onset and persistence of suicidal behaviour. British Journal of Psychiatry. 2010; 197(1):20-27. doi:10.1192/bjp.bp.109.074716. [PubMed: 20592429]

Bruffaerts R, Demyttenaere K, Hwang I, Chiu WT, Sampson N, Kessler RC, Nock MK. Treatment of suicidal people around the world. British Journal of Psychiatry. 2011; 199:64-70. doi:10.1192/ bjp.bp.110.084129. [PubMed: 21263012]

Bush NE, Skopp NA, McCann R, Luxton DD. Posttraumatic growth as protection against suicidal ideation after deployment and combat exposure. Military Medicine. 2011; 176(11):1215-1222. [PubMed: 22165648]

Carter G, Reith DM, Whyte IM, McPherson M. Repeated self-poisoning: Increasing severity of selfharm as a predictor of subsequent suicide. British Journal of Psychiatry. 2005; 186(3):253-257. [PubMed: 15738507]

Cavallaro, G. Transition unit spc. kills self in Colo. home. Army Times. Feb 1. 2009 http:// www.armytimes.com/news/2009/02/army_applegate_death_020209w/

Cavanagh JT, Carson AJ, Sharpe M, Lawrie SM. Psychological autopsy studies of suicide: A systematic review. Psychological Medicine. 2003; 33(3):395-405. [PubMed: 12701661]

Centers for Disease Control and Prevention, National Center for Injury Prevention and Control. Webbased Injury Statistics Query and Reporting System (WISQARS) [online]. 2013. Available from www.cdc.gov/ncipc/wisqars

Cha CB, Nock MK. Emotional intelligence is a protective factor for suicidal behavior. Journal of the American Academy of Child and Adolescent Psychiatry. 2009; 48(4):422-430. [PubMed: 19318882]

Christiansen E, Jensen BF. Risk of repetition of suicide attempt, suicide or all deaths after an episode of attempted suicide: A register-based survival analysis. Australia New Zealand Journal of Psychiatry. 2007; 4(13):8.

Conner KR, Swogger MT, Houston RJ. A test of the reactive aggression-suicidal behavior hypothesis: Is there a case for proactive aggression? Journal of Abnormal Psychology. 2009; 118(1):235-240. [PubMed: 19222330]

Dao, J.; Frosch, D. Feeling warehoused in Army trauma care units. New York Times; Apr 24. 2010 http://www.nytimes.com/2010/04/25/health/25warrior.html?pagewanted=all

Davidson RJ, Putnam KM, Larson CL. Dysfunction in the neural circuitry of emotion regulation-a possible prelude to violence. Science. 2000; 289(5479):591-594. doi:10.1126/science. 289.5479.591. [PubMed: 10915615]

Defense Manpower Data Center. Global War on Terrorism - Operation New Dawn By Month. Sep 1.2012a 2010 Through May 7, 2012.

Defense Manpower Data Center. Global War on Terrorism - Operation Enduring Freedom By Month. Oct 7.2012b 2001 through May 7, 2012.

Defense Manpower Data Center. Global War on Terrorism - Operation Iraqi Freedom By Month. Mar 19.2012c 2003 Through May 7, 2012. 
Dervic K, Oquendo MA, Grunebaum MF, Ellis S, Burke AK, Mann JJ. Religious affiliation and suicide attempt. American Journal of Psychiatry. 2004; 161(12):2303-2308. [PubMed: 15569904]

Dimeff L, Linehan MM. Dialectical behavior therapy in a nutshell. California Psychologist. 2001; 34:10-13.

Diorio D, Viau V, Meaney MJ. The role of the medial prefrontal cortex (cingulate gyrus) in the regulation of hypothalamic-pituitary-adrenal responses to stress. Journal of Neuroscience. 1993; 13(9):3839-3847. [PubMed: 8396170]

Dixon WA, Rumford KG, Heppner PP, Lips BJ. Use of different sources of stress to predict hopelessness and suicide ideation in a college population. Journal of Counseling Psychology. 1992; 39(3):342-349.

Druss B, Pincus H. Suicidal ideation and suicide attempts in general medical illnesses. Archives of Internal Medicine. 2000; 160(10):1522-1526. doi:10.1001/archinte.160.10.1522. [PubMed: 10826468]

Dube SR, Anda RF, Felitti VJ, Chapman DP, Williamson DF, Giles WH. Childhood abuse, household dysfunction, and the risk of attempted suicide throughout the life span: Findings from the Adverse Childhood Experiences Study. Journal of the American Medical Association. 2001; 286(24):30893096. [PubMed: 11754674]

Dulit RA, Fyer MR, Leon AC, Brodsky BS, Frances AJ. Clinical correlates of self-mutilation in borderline personality disorder. American Journal of Psychiatry. 1994; 151(9):1305-1311. [PubMed: 8067485]

Edwards-Stewart A, Kinn JT, June JD, Fullerton NR. Military and civilian media coverage of suicide. Archives of Suicide Research. 2011; 15(4):304-312. doi:10.1080/13811118.2011.615692. [PubMed: 22023639]

Ellis TE. Collaboration and a self-help orientation in therapy with suicidal clients. Journal of Contemporary Psychotherapy. 2004; 34:41-57.

Ellis TE, Allen JG, Woodson H, Frueh BC, Jobes DA. Implementing an evidence-based approach to working with suicidal inpatients. Bulletin of the Menninger Clinic. 2009; 73:339-354. [PubMed: 20025428]

Fava GA, Ruini C, Rafanelli C, Finos L, Conti S, Grandi S. Six-year outcome of cognitive behavior therapy for prevention of recurrent depression. American Journal of Psychiatry. 2004; 161(10): 1872-1876. [PubMed: 15465985]

Fawcett J. Treating impulsivity and anxiety in the suicidal patient. Annals of the New York Academy of Sciences. 2001; 932:94-102. [PubMed: 11411193]

Fawcett J, Busch KA, Jacobs D, Kravitz HM, Fogg L. Suicide: A four-pathway clinical-biochemical model. Annals of the New York Academy of Sciences. 1997; 836:288-301. [PubMed: 9616805]

Fawcett J, Scheftner WA, Fogg L, Clark DC, Young MA, Hedeker D, Gibbons R. Time-related predictors of suicide in major affective disorder. American Journal of Psychiatry. 1990; 147(9): 1189-1194. [PubMed: 2104515]

Ghahramanlou-Holloway M, Bhar SS, Brown GK, Olsen C, Beck AT. Changes in problem-solving appraisal after cognitive therapy for the prevention of suicide. Psychological Medicine. 2012; 42(6):1185-1193. doi:10.1017/S0033291711002169. [PubMed: 22008384]

Ghahramanlou-Holloway, M.; Brown, GK.; Beck, AT. Suicide.. In: Whisman, MA., editor. Adapting cognitive therapy for depression: Managing complexity and comorbidity. Guilford Press; New York: 2008. p. 159-184.

Gogtay N, Giedd J, Lusk L, Hayashi KM, Greenstein D, Vaituzis AC, Thompson PM. Dynamic mapping of human cortical development during childhood through early adulthood. Proceedings of the National Academy of Sciences. 2004; 101:8174-8179.

Bunney, WE. Reducing suicide: A national imperative. Goldsmith, SK.; Pellmar, TC.; Kleinman, AM., editors. National Academies Press; Washington, DC: 2002.

Gould MS. Suicide and the media. Annals of the New York Academy of Sciences. 2001; 932:200221. discussion, 221-224. [PubMed: 11411187]

Gould MS, King R, Greenwald S, Fisher P, Schwab-Stone M, Kramer R, Shaffer D. Psychopathology associated with suicidal ideation and attempts among children and adolescents. Journal of the American Academy of Child \& Adolescent Psychiatry. 1998; 37(9):915-923. [PubMed: 9735611] 
Grafman J, Schwab K, Warden D, Pridgen A, Brown HR, Salazar AM. Frontal lobe injuries, violence, and aggression: A report of the Vietnam Head Injury Study. Neurology. 1996; 46(5):1231-1238. [PubMed: 8628458]

Griffith J. Multilevel analysis of cohesion's relation to stress, well-being, identification, disintegration, and perceived combat readiness. Military Psychology. 2002; 14(3):217-239.

Gureje O, Oladeji B, Hwang I, Chiu WT, Kessler RC, Sampson NA, Nock MK. Parental psychopathology and the risk of suicidal behavior in their offspring: Results from the World Mental Health surveys. Molecular Psychiatry. 2011; 16(12):1221-1233. doi:10.1038/mp. 2010.111. [PubMed: 21079606]

Halverson, RR.; Bliese, PD.; Moore, RE.; Castro, CA. Psychological well-being and physical health of soldiers deployed for Operation Uphold Democracy: A summary of human dimensions research in Haiti. Defense Technical Information Center; Alexandria, VA: 1995. DTIC: \#ADA298125

Harris EC, Barraclough B. Suicide as an outcome for mental disorders. A meta-analysis. British Journal of Psychiatry. 1997; 170:205-228. [PubMed: 9229027]

Hawton K, Houston K, Haw C, Townsend E, Harriss L. Comorbidity of Axis I and Axis II disorders in patients who attempted suicide. American Journal of Psychiatry. 2003; 160(8):1494-1500. [PubMed: 12900313]

Higley JD, Linnoila M. Low central nervous system serotonergic activity is traitlike and correlates with impulsive behavior. A non-human primate model investigating genetic and environmental influences on neurotransmission. Annals of the New York Academy of Sciences. 1997; 836:3956. [PubMed: 9616793]

Hill JV, Johnson RC, Barton RA. Suicidal and homicidal soldiers in deployment environments. Military Medicine. 2006; 171(3):228-232. [PubMed: 16602522]

Hoge CW, Auchterlonie JL, Milliken CS. Mental health problems, use of mental health services, and attrition from military service after returning from deployment to Iraq or Afghanistan. Journal of the American Medical Association. 2006; 295(9):1023-1032. [PubMed: 16507803]

Hoge CW, Castro CA, Messer SC, McGurk D, Cotting DI, Koffman RL. Combat duty in Iraq and Afghanistan, mental health problems, and barriers to care. New England Journal of Medicine. 2004; 351(1):13-22. [PubMed: 15229303]

Hoge CW, McGurk D, Thomas JL, Cox AL, Engel CC, Castro CA. Mild traumatic brain injury in U.S. soldiers returning from Iraq. New England Journal of Medicine. 2008; 358(5):453-463. doi: 10.1056/NEJMoa072972. [PubMed: 18234750]

Hyman J, Ireland R, Frost L, Cottrell L. Suicide incidence and risk factors in an active duty U.S. military population. American Journal of Public Health. 2012; 102(Suppl. 1):S138-146. doi: 10.2105/AJPH.2011.300484. [PubMed: 22390588]

Ingram, RE.; Luxton, DD. Vulnerability-stress models.. In: Hankin, BL.; Abela, JRZ., editors. Development of psychopathology: A vulnerability-stress perspective. Sage; London: 2005. p. 32-46.

Jobes DA. Collaborating to prevent suicide: A clinical-research perspective. Suicide \& LifeThreatening Behavior. 2000; 30(1):8-17. [PubMed: 10782715]

Jobes, DA. Managing suicidal risk: A collaborative approach. Guilford; New York: 2006.

Jobes DA, Wong SA, Conrad AK, Drozd JF, Neal-Walden T. The collaborative assessment and management of suicidality versus treatment as usual: A retrospective study with suicidal outpatients. Suicide \& Life Threatening Behavior. 2005; 35(5):483-497. doi:10.1521/suli. 2005.35.5.483. [PubMed: 16268766]

Johnson J, Wood AM, Gooding P, Taylor PJ, Tarrier N. Resilience to suicidality: The buffering hypothesis. Clinical Psychology Review. 2011; 31(4):563-591. doi:10.1016/j.cpr.2010.12.007. [PubMed: 21276646]

Joiner TE, Conwell Y, Fitzpatrick KK, Witte TK, Schmidt NB, Berlim MT, Rudd MD. Four studies on how past and current suicidality relate even when "everything but the kitchen sink" is covaried. Journal of Abnormal Psychology. 2005; 114(2):291-303. [PubMed: 15869359]

Joiner TE, Sachs-Ericsson NJ, Wingate LR, Brown JS, Anestis MD, Selby EA. Childhood physical and sexual abuse and lifetime number of suicide attempts: A persistent and theoretically important relationship. Behaviour Research and Therapy. 2007; 45(3):539-547. [PubMed: 16765909] 
Jollant F, Bellivier F, Leboyer M, Astruc B, Torres S, Verdier R, Courtet P. Impaired decision making in suicide attempters. American Journal of Psychiatry. 2005; 162(2):304-310. [PubMed: 15677595]

Kaskutas LA, Weisner C, Caetano R. Predictors of help seeking among a longitudinal sample of the general population, 1984-1992. Journal of Studies on Alcohol. 1997; 58(2):155-161. [PubMed: 9065893]

Keilp JG, Gorlyn M, Oquendo MA, Brodsky B, Ellis SP, Stanley B, John Mann J. Aggressiveness, not impulsiveness or hostility, distinguishes suicide attempters with major depression. Psychological Medicine. 2006; 36(12):1779-1788. [PubMed: 16959059]

Keilp JG, Gorlyn M, Oquendo MA, Burke AK, Mann JJ. Attention deficit in depressed suicide attempters. Psychiatry Research. 2008; 159(1-2):7-17. doi:10.1016/j.psychres.2007.08.020. [PubMed: 18329724]

Kenyon, HS. U.S. Army reforges training and readiness, Signal Magazine Online. 2006. https:// www.afcea.org/signal/articles/templates/SIGNAL_Article_Template.asp? articleid $=1139 \&$ zoneid $=185$

Kessler RC, Berglund P, Borges G, Nock MK, Wang PS. Trends in suicide ideation, plans, gestures, and attempts in the United States, 1990-1992 to 2001-2003. Journal of the American Medical Association. 2005; 293:2487-2495. [PubMed: 15914749]

Kessler RC, Berglund P, Demler O, Jin R, Merikangas KR, Walters EE. Lifetime prevalence and ageof-onset distributions of DSM-IV disorders in the National Comorbidity Survey Replication. Archives of General Psychiatry. 2005; 62(6):593-602. [PubMed: 15939837]

Kessler RC, Borges G, Walters EE. Prevalence of and risk factors for lifetime suicide attempts in the National Comorbidity Survey. Archives of General Psychiatry. 1999; 56(7):617-626. [PubMed: 10401507]

Kessler RC, Chiu WT, Demler O, Merikangas KR, Walters EE. Prevalence, severity, and comorbidity of 12-month DSM-IV disorders in the National Comorbidity Survey Replication. Archives of General Psychiatry. 2005; 62(6):617-627. [PubMed: 15939839]

Kim E. Agitation, aggression, and disinhibition syndromes after traumatic brain injury. NeuroRehabilitation. 2002; 17(4):297-310. [PubMed: 12547978]

King M, Dinos S, Shaw J, Watson R, Stevens S, Passetti F, Serfaty M. The Stigma Scale: Development of a standardised measure of the stigma of mental illness. British Journal of Psychiatry. 2007; 190:248-254. [PubMed: 17329746]

Knox KL, Litts DA, Talcott GW, Feig JC, Caine ED. Risk of suicide and related adverse outcomes after exposure to a suicide prevention programme in the U.S. Air Force: Cohort study. BMJ. 2003; 327(7428):1376. doi:10.1136/bmj.327.7428.1376. [PubMed: 14670880]

Knox KL, Pflanz S, Talcott GW, Campise RL, Lavigne JE, Bajorska A, Caine ED. The U.S. Air Force suicide prevention program: Implications for public health policy. American Journal of Public Health. 2010; 100(12):2457-2463. doi:10.2105/AJPH.2009.159871. [PubMed: 20466973]

Knox KL, Stanley B, Currier GW, Brenner L, Ghahramanlou-Holloway M, Brown G. An emergency department-based brief intervention for veterans at risk for suicide (SAFE VET). American Journal of Public Health. 2012; 102(Suppl. 1):S33-37. doi:10.2105/AJPH.2011.300501. [PubMed: 22390597]

Koons CR, Robins CJ, Tweed JL, Lynch TR, Gonzalez AM, Morse JQ, Bastian LA. Efficacy of dialectical behavior therapy in women veterans with borderline personality disorder. Behavior Therapy. 2001; 32:371-390.

Kraemer GW, Schmidt DE, Ebert MH. The behavioral neurobiology of self-injurious behavior in rhesus monkeys. Current concepts and relations to impulsive behavior in humans. Annals of the New York Academy of Science. 1997; 836:12-38.

Kreutzer JS, Seel RT, Gourley E. The prevalence and symptom rates of depression after traumatic brain injury: A comprehensive examination. Brain Injury. 2001; 15(7):563-576. doi: 10.1080/02699050010009108. [PubMed: 11429086]

Kuehn BM. Soldier suicide rates continue to rise: Military, scientists work to stem the tide. Journal of the American Medical Association. 2009; 301:1112-1113.

Levin A. Combat just one cause of army suicide crisis. Psychiatric News. 2009; 44:4. 
Linehan, MM. Cognitive-behavioral treatment of borderline personality disorder. Guilford; New York: 1993.

Linehan MM, Armstrong HE, Suarez A, Allmon D, Heard HL. Cognitive-behavioral treatment of chronically parasuicidal borderline patients. Archives of General Psychiatry. 1991; 48(12):10601064. [PubMed: 1845222]

Linehan MM, Comtois KA, Murray AM, Brown MZ, Gallop RJ, Heard HL, Lindenboim N. Two-year randomized controlled trial and follow-up of dialectical behavior therapy vs. therapy by experts for suicidal behaviors and borderline personality disorder. Archives of General Psychiatry. 2006; 63(7):757-766. [PubMed: 16818865]

Linehan, MM.; Rizvi, SL.; Welch, SS.; Page, B. Psychiatric aspects of suicidal behaviour: Personality disorders.. In: Hawton, K.; van Heeringen, K., editors. International handbook of suicide and attempted suicide. Wiley; Chichester, England: 2000. p. 147-178.

Linley PA, Joseph S. Positive change following trauma and adversity: A review. Journal of Traumatic Stress. 2004; 17(1):11-21. [PubMed: 15027788]

Logan J, Skopp NA, Karch D, Reger MA, Gahm GA. Characteristics of suicides among U.S. army active duty personnel in 17 U.S. states from 2005 to 2007. American Journal of Public Health. 2012; 102(Suppl. 1):S40-44. doi:10.2105/AJPH.2011.300481. [PubMed: 22390599]

Lyons-Ruth, K.; Jacobvitz, D. Attachment disorganization: Genetic factors, parenting contexts, and developmental transformation from infancy to adulthood.. In: Cassidy, J.; Shaver, PR., editors. Handbook of attachment: Theory, research, and clinical applications. 2nd ed.. Guilford; New York: 2008. p. 666-697.

Mann JJ, Apter A, Bertolote J, Beautrais A, Currier D, Haas A, Hendin H. Suicide prevention strategies: A systematic review. Journal of the American Medical Association. 2005; 294(16): 2064-2074. [PubMed: 16249421]

Mann JJ, Waternaux C, Haas GL, Malone KM. Toward a clinical model of suicidal behavior in psychiatric patients. American Journal of Psychiatry. 1999; 156(2):181-189. [PubMed: 9989552]

Marzuk PM, Tardiff K, Leon AC, Hirsch CS, Portera L, Hartwell N, Iqbal MI. Lower risk of suicide during pregnancy. American Journal of Psychiatry. 1997; 154(1):122-123. [PubMed: 8988973]

McCarthy MD, Thompson SJ, Knox KL. Use of the Air Force Post-Deployment Health Reassessment for the identification of depression and posttraumatic stress disorder: Public health implications for suicide prevention. American Journal of Public Health. 2012; 102(Suppl. 1):S60-65. doi: 10.2105/AJPH.2011.300580. [PubMed: 22390604]

McGirr A, Turecki G. The relationship of impulsive aggressiveness to suicidality and other depression-linked behaviors. Current Psychiatry Reports. 2007; 9(6):460-466. [PubMed: 18221625]

McGowan PO, Sasaki A, D'Alessio AC, Dymov S, Labonte B, Szyf M, Meaney MJ. Epigenetic regulation of the glucocorticoid receptor in human brain associates with childhood abuse. Nature Neuroscience. 2009; 12(3):342-348. doi:10.1038/nn.2270.

McLaughlin KA, Hatzenbuehler ML. Mechanisms linking stressful life events and mental health problems in a prospective, community-based sample of adolescents. Journal of Adolescent Health. 2009; 44:153-160. [PubMed: 19167664]

Mead GE, Morley W, Campbell P, Greig CA, McMurdo M, Lawlor DA. Exercise for depression. Cochrane Database of Systematic Reviews. 2008; (4):CD004366. [PubMed: 18843656]

Miller M, Hemenway D. Guns and suicide in the United States. New England Journal of Medicine. 2008; 359(10):989-991. [PubMed: 18768940]

Moscicki, EK. Epidemiology of suicide.. In: Jacobs, DG., editor. The Harvard Medical School guide to suicide assessment and intervention. Jossey-Bass; San Francisco, CA: 1999. p. 40-51.

National Vital Statistics System, National Center for Health Statistics, Centers for Disease Control. 10 Leading Causes of Death by Age Group, United States - 2008. (CS227502). 2008. http:// www.cdc.gov/Injury/wisqars/pdf/10LCD-Age-Grp-US-2008-a.pdf

Nelson R. Suicide rates rise among soldiers in Iraq. Lancet. 2004; 363:300. [PubMed: 14753211]

Nisbett RE, Wilson TD. Telling more than we can know: Verbal reports on mental processes. Psychological Review. 1977; 84(3):231-259. 
Nock MK. Actions speak louder than words: An elaborated theoretical model of the social functions of self-injury and other harmful behaviors. Applied and Preventive Psychology. 2008; 12:159-168. [PubMed: 19122893]

Nock, MK. Understanding nonsuicidal self-injury: Origins, assessment, and treatment. American Psychological Association; Washington, DC: 2009a.

Nock MK. Why do people hurt themselves? New insights into the nature and function of self-injury. Current Directions in Psychological Science. 2009b; 18:78-83. [PubMed: 20161092]

Nock MK, Borges G, Bromet EJ, Alonso J, Angermeyer M, Beautrais A, Williams D. Cross-national prevalence and risk factors for suicidal ideation, plans, and attempts in the WHO World Mental Health Surveys. British Journal of Psychiatry. 2008; 192:98-105. [PubMed: 18245022]

Nock MK, Borges G, Bromet EJ, Cha CB, Kessler RC, Lee S. Suicide and suicidal behavior. Epidemiologic Reviews. 2008; 30:133-154. [PubMed: 18653727]

Nock MK, Hwang I, Sampson N, Kessler RC. Mental disorders, comorbidity, and suicidal behaviors: Results from the National Comorbidity Survey Replication. Molecular Psychiatry. 2010; 15(8): 868-876. [PubMed: 19337207]

Nock MK, Hwang I, Sampson N, Kessler RC, Angermeyer M, Beautrais A, Williams DR. Crossnational analysis of the associations among mental disorders and suicidal behavior: Findings from the WHO World Mental Health Surveys. PLOS Medicine. 2009; 6:e1000123. [PubMed: 19668361]

Nock MK, Joiner TE Jr. Gordon KH, Lloyd-Richardson E, Prinstein MJ. Non-suicidal self-injury among adolescents: Diagnostic correlates and relation to suicide attempts. Psychiatry Research. 2006; 144:65-72. [PubMed: 16887199]

Nock MK, Kazdin AE. Examination of affective, cognitive, and behavioral factors and suicide-related outcomes in children and young adolescents. Journal of Clinical Child and Adolescent Psychology. 2002; 31:48-58. [PubMed: 11845650]

Nock MK, Kessler RC. Prevalence of and risk factors for suicide attempts versus suicide gestures: Analysis of the National Comorbidity Survey. Journal of Abnormal Psychology. 2006; 115:616623. [PubMed: 16866602]

Nock, MK.; Marzuk, PM. Suicide and violence.. In: Hawton, K.; van Heeringen, K., editors. International handbook of suicide and attempted suicide. Wiley; Chichester, England: 2000. p. 437-456.

Nock MK, Wedig MM, Holmberg EB, Hooley JM. Emotion reactivity scale: Psychometric evaluation and relation to self-injurious thoughts and behaviors. Behavior Therapy. 2008; 39:107-116. [PubMed: 18502244]

Ochsner KN, Ray RD, Cooper JC, Robertson ER, Chopra S, Gabrieli JDE. For better or for worse: Neural systems supporting the cognitive down- and up-regulation of negative emotion. Neuroimage. 2004; 23:483-499. [PubMed: 15488398]

Oquendo MA, Bongiovi-Garcia ME, Galfalvy H, Goldberg PH, Grunebaum MF, Burke AK, Mann JJ. Sex differences in clinical predictors of suicidal acts after major depression: A prospective study. American Journal of Psychiatry. 2007; 164(1):134-141. doi:10.1176/ appi.ajp.164.1.134. [PubMed: 17202555]

Oquendo MA, Dragatsi D, Harkavy-Friedman J, Dervic K, Currier D, Burke AK, Mann JJ. Protective factors against suicidal behavior in Latinos. Journal of Nervous \& Mental Disease. 2005; 193(7): 438-443. [PubMed: 15985837]

Oquendo MA, Galfalvy H, Russo S, Ellis SP, Grunebaum MF, Burke AK, Mann JJ. Prospective study of clinical predictors of suicidal acts after a major depressive episode in patients with major depressive disorder or bipolar disorder. American Journal of Psychiatry. 2004; 161(8):14331441. doi:10.1176/appi.ajp.161.8.1433. [PubMed: 15285970]

Park CL, Cohen LH, Murch RL. Assessment and prediction of stress-related growth. Journal of Personality. 1996; 64(1):71-105. [PubMed: 8656319]

Payne SE, Hill JV, Johnson DE. The use of Unit Watch or Command Interest Profile in the management of suicide and homicide risk: Rationale and guidelines for the military mental health professional. Military Medicine. 2008; 173(1):25-35. [PubMed: 18251328] 
Perlis RH, Huang J, Purcell S, Fava M, Rush AJ, Sullivan PF, Smoller JW. Genome-wide association study of suicide attempts in mood disorder patients. American Journal of Psychiatry. 2010; 167(12):1499-1507. doi:10.1176/appi.ajp.2010.10040541. [PubMed: 21041247]

Peterson C, Park N, Pole N, D'Andrea W, Seligman ME. Strengths of character and posttraumatic growth. Journal of Traumatic Stress. 2008; 21(2):214-217. [PubMed: 18404632]

Petronis KR, Samuels JF, Moscicki EK, Anthony JC. An epidemiologic investigation of potential risk factors for suicide attempts. Social Psychiatry and Psychiatric Epidemiology. 1990; 25:193-199. [PubMed: 2399476]

Phillips DP. The influence of suggestion on suicide: substantive and theroretical implications of the Werther effect. American Sociological Review. 1974; 39(3):340-354.

Phillips MR, Yang G, Zhang Y, Wang L, Ji H, Zhou M. Risk factors for suicide in China: A national case-control psychological autopsy study. Lancet. 2002; 360(9347):1728-1736. [PubMed: 12480425]

Platt S, Bille-Brahe U, Kerkhof A, Schmidtke A, Bjerke T, Crepet P, et al. Parasuicide in Europe: The WHO/EURO multicentre study on parasuicide. I. Introduction and preliminary analysis for 1989. Acta Psychiatrica Scandanavica. 1992; 85(2):97-104.

Pollak SD, Nelson CA, Schlaak MF, Roeber BJ, Wewerka S, Wiik KL, Gunnar MR. Neurodevelopmental effects of early deprivation in postinstitutionalized children. Child Development. 2010; 81:224-236. [PubMed: 20331664]

Prinstein MJ, Nock MK, Simon V, Aikens JW, Cheah CSL, Spirito A. Longitudinal trajectories and predictors of adolescent suicidal ideation and attempts following inpatient hospitalization. Journal of Consulting and Clinical Psychology. 2008; 76(1):92-103. [PubMed: 18229987]

Qin P, Mortensen PB. The impact of parental status on the risk of completed suicide. Archives of General Psychiatry. 2003; 60(8):797-802. [PubMed: 12912763]

Radley JJ, Rocher AB, Miller M, Janssen WG, Liston C, Hof PR, Morrison JH. Repeated stress induces dendritic spine loss in the rat medial prefrontal cortex. Cerebral Cortex. 2006; 16(3): 313-320. doi:10.1093/cercor/bhi104. [PubMed: 15901656]

Rao V, Lyketsos C. Neuropsychiatric sequelae of traumatic brain injury. Psychosomatics. 2000; 41(2): 95-103. doi:10.1176/appi.psy.41.2.95. [PubMed: 10749946]

Ribeiro JD, Pease JL, Gutierrez PM, Silva C, Bernert RA, Rudd MD, Joiner TE Jr. Sleep problems outperform depression and hopelessness as cross-sectional and longitudinal predictors of suicidal ideation and behavior in young adults in the military. Journal of Affective Disorders. 2012; 136(3):743-750. doi:10.1016/j.jad.2011.09.049. [PubMed: 22032872]

Ridderinkhof KR, van den Wildenberg WP, Segalowitz SJ, Carter CS. Neurocognitive mechanisms of cognitive control: The role of prefrontal cortex in action selection, response inhibition, performance monitoring, and reward-based learning. Brain Cogn. 2004; 56(2):129-140. doi: 10.1016/j.bandc.2004.09.016. [PubMed: 15518930]

Ritchie EC, Keppler WC, Rothberg JM. Suicidal admissions in the United States military. Military Medicine. 2003; 168(3):177-181. [PubMed: 12685680]

Rosenbaum JE. Gun utopias? Firearm access and ownership in Israel and Switzerland. Journal of Public Health Policy. 2012; 33(1):46-58. doi:10.1057/jphp.2011.56. [PubMed: 22089893]

Rudd MD, Berman AL, Joiner TE Jr. Nock MK, Silverman MM, Mandrusiak M, Witte T. Warning signs for suicide: Theory, research, and clinical applications. Suicide and Life-Threatening Behavior. 2006; 36(3):255-262. [PubMed: 16805653]

Sadowski C, Kelley ML. Social problem solving in suicidal adolescents. Journal of Consulting and Clinical Psychology. 1993; 61(1):121-127. [PubMed: 8450097]

Schneiderman AI, Braver ER, Kang HK. Understanding sequelae of injury mechanisms and mild traumatic brain injury incurred during the conflicts in Iraq and Afghanistan: Persistent postconcussive symptoms and post-traumatic stress disorder. American Journal of Epidemiology. 2008; 167(12):1446-1452. doi:10.1093/aje/kwn068. [PubMed: 18424429]

Scott KM, Hwang I, Chiu WT, Kessler RC, Sampson NA, Angermeyer M, Nock MK. Chronic physical conditions and their association with first onset of suicidal behavior in the world mental health surveys. Psychosomatic Medicine. 2010; 72(7):712-719. doi:10.1097/PSY.

0b013e3181e3333d. [PubMed: 20498290] 
Seligman ME, Fowler RD. Comprehensive soldier fitness and the future of psychology. American Psychologist. 2011; 66(1):82-86. doi:10.1037/a0021898. [PubMed: 21219053]

Seligman ME, Steen TA, Park N, Peterson C. Positive psychology progress: Empirical validation of interventions. American Psychologist. 2005; 60(5):410-421. [PubMed: 16045394]

Shaffer D, Gould MS, Fisher P, Trautman P, Moreau D, Kleinman M, Flory M. Psychiatric diagnosis in child and adolescent suicide. Archives of General Psychiatry. 1996; 53(4):339-348. [PubMed: 8634012]

Shafii M, Carrigan S, Whittinghill JR, Derrick A. Psychological autopsy of completed suicide in children and adolescents. American Journal of Psychiatry. 1985; 142(9):1061-1064. [PubMed: 4025622]

Shafii M, Steltz-Lenarsky J, Derrick AM, Beckner C, Whittinghill JR. Comorbidity of mental disorders in the post-mortem diagnosis of completed suicide in children and adolescents. Journal of Affective Disorders. 1988; 15(3):227-233. [PubMed: 2975295]

Silverman MM, Berman AL, Sanddal ND, O'Carroll P W, Joiner TE. Rebuilding the tower of Babel: A revised nomenclature for the study of suicide and suicidal behaviors. Part 2: Suicide-related ideations, communications, and behaviors. Suicide and Life-Threatening Behavior. 2007; 37(3): 264-277. doi:10.1521/suli.2007.37.3.264. [PubMed: 17579539]

Simpson G, Tate R. Suicidality after traumatic brain injury: Demographic, injury and clinical correlates. Psychological Medicine. 2002; 32(4):687-697. [PubMed: 12102383]

Sonneck G, Etzersdorfer E, Nagel-Kuess S. Imitative suicide on the Viennese subway. Social Science and Medicine. 1994; 38(3):453-457. [PubMed: 8153751]

Southwick, SM.; Litz, BT.; Charney, D.; Friedman, MJ., editors. Resilience and mental health: Challenges across the lifespan. Cambridge University Press; New York: 2012.

Stanley B, Brown GK. Safety planning intervention: A brief intervention to mitigate suicide risk. Cognitive and Behavioral Practice. 2012; 19:256-264.

Stein DJ, Chiu WT, Hwang I, Kessler RC, Sampson N, Alonso J, Nock MK. Cross-national analysis of the associations between traumatic events and suicidal behavior: Findings from the WHO World Mental Health Surveys. PLoS One. 2010; 5(5):e10574. doi:10.1371/journal.pone.0010574. [PubMed: 20485530]

STRONG STAR. The South Texas Research Organizational Network Guiding Studies on Trauma and Resilience. 2012. http://delta.uthscsa.edu/strongstar/index.asp

Suicide Prevention Resource Center. At-a-glance: Safe reporting on suicide. 2007. http:// www.sprc.org/sites/sprc.org/files/library/at_a_glance.pdf

Teasdale TW, Engberg AW. Suicide after traumatic brain injury: A population study. Journal of Neurology, Neurosurgery \& Psychiatry. 2001; 71(4):436-440.

Teicher MH, Andersen SL, Polcari A, Anderson CM, Navalta CP, Kim DM. The neurobiological consequences of early stress and childhood maltreatment. Neuroscience \& Biobehavioral Reviews. 2003; 27(1-2):33-44. [PubMed: 12732221]

Tucker GJ, Gorman ER. The significance of the suicide gesture in the military. American Journal of Psychiatry. 1967; 123(7):854-861. [PubMed: 6016857]

Turecki G, Ernst C, Jollant F, Labonte B, Mechawar N. The neurodevelopmental origins of suicidal behavior. Trends in Neurosciences. 2012; 35(1):14-23. [PubMed: 22177979]

Verheul R, Van Den Bosch LM, Koeter MW, De Ridder MA, Stijnen T, Van Den Brink W. Dialectical behaviour therapy for women with borderline personality disorder: 12-month, randomised clinical trial in The Netherlands. British Journal of Psychiatry. 2003; 182:135-140. [PubMed: 12562741]

Vijayakumar L, Rajkumar S. Are risk factors for suicide universal? A case-control study in India. Acta Psychiatrica Scandinavica. 1999; 99(6):407-411. [PubMed: 10408261]

Wang PS, Aguilar-Gaxiola S, Alonso J, Angermeyer MC, Borges G, Bromet EJ, Wells JE. Use of mental health services for anxiety, mood, and substance disorders in 17 countries in the WHO world mental health surveys. Lancet. 2007; 370(9590):841-850. [PubMed: 17826169]

Wang PS, Angermeyer M, Borges G, Bruffaerts R, Tat Chiu W, G, D. E. G. Ustun TB. Delay and failure in treatment seeking after first onset of mental disorders in the World Health 
Organization's World Mental Health Survey Initiative. World Psychiatry. 2007; 6(3):177-185. [PubMed: 18188443]

Wang PS, Berglund P, Olfson M, Pincus HA, Wells KB, Kessler RC. Failure and delay in initial treatment contact after first onset of mental disorders in the National Comorbidity Survey Replication. Archives of General Psychiatry. 2005; 62(6):603-613. [PubMed: 15939838]

Wang PS, Gruber MJ, Powers RE, Schoenbaum M, Speier AH, Wells KB, Kessler RC. Disruption of existing mental health treatments and failure to initiate new treatment after hurricane katrina. American Journal of Psychiatry. 2008; 165(1):34-41. [PubMed: 18086749]

Warden D. Military TBI during the Iraq and Afghanistan wars. Journal of Head Trauma Rehabilitation. 2006; 21(5):398-402. [PubMed: 16983225]

Weyrauch KF, Roy-Byrne P, Katon W, Wilson L. Stressful life events and impulsiveness in failed suicide. Suicide and Life-Threatening Behavior. 2001; 31(3):311-319. [PubMed: 11577915]

Wichers M, Schrijvers D, Geschwind N, Jacobs N, Myin-Germeys I, Thiery E, van Os J. Mechanisms of gene-environment interactions in depression: Evidence that genes potentiate multiple sources of adversity. Journal of Psychological Medicine. 2009; 39(7):1077-1086. doi:10.1017/ S0033291708004388.

Wieland DM, Haley JL, Bouder M. Military sexual trauma. Pennsylvania Nurse. 2011; 66(4):17-19. 21. [PubMed: 22359967]

Wilkinson P, Kelvin R, Roberts C, Dubicka B, Goodyer I. Clinical and psychosocial predictors of suicide attempts and nonsuicidal self-injury in the Adolescent Depression Antidepressants and Psychotherapy Trial (ADAPT). American Journal of Psychiatry. 2011; 168(5):495-501. doi: 10.1176/appi.ajp.2010.10050718. [PubMed: 21285141]

Williams LM, Kemp AH, Felmingham K, Barton M, Olivieri G, Peduto A, Bryant RA. Trauma modulates amygdala and medial prefrontal responses to consciously attended fear. Neuroimage. 2006; 29(2):347-357. doi:10.1016/j.neuroimage.2005.03.047. [PubMed: 16216534]

World Health Organization. The global burden of disease: 2004 update. 2008. http://www.who.int/ healthinfo/global_burden_disease/GBD_report_2004update_full.pdf

Yen S, Pagano ME, Shea MT, Grilo CM, Gunderson JG, Skodol AE, Zanarini MC. Recent life events preceding suicide attempts in a personality disorder sample: Findings from the collaborative longitudinal personality disorders study. Journal of Consulting and Clinical Psychology. 2005; 73(1):99-105. [PubMed: 15709836]

Zouk H, Tousignant M, Seguin M, Lesage A, Turecki G. Characterization of impulsivity in suicide completers: Clinical, behavioral and psychosocial dimensions. Journal of Affective Disorders. 2006; 92(2-3):195-204. [PubMed: 16545465] 


\section{Comparison of Suicide Rates: Active Duty Army \& Demographically Matched Civilians*}

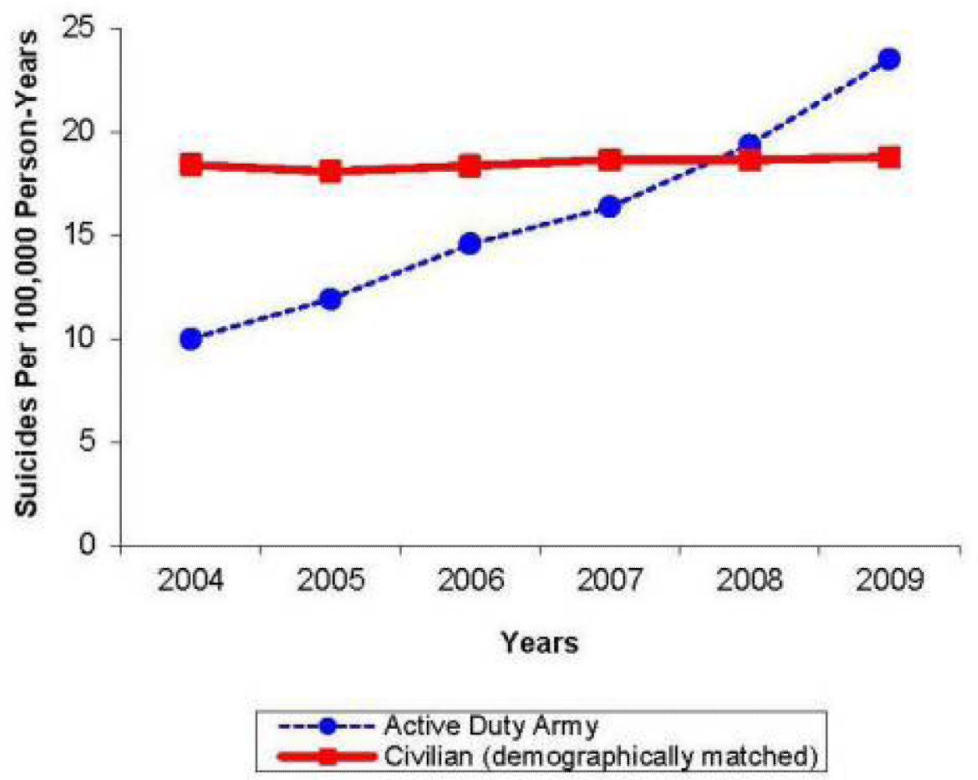

FIGURE 1.

Comparison of Suicide Rates: Active Duty Army and Demographically Matched Civilians. Army rates calculated by Army STARRS based on data provided by the Defense Manpower Data Center (https://www. dmdc.osd.mil/appj/dwp/index.jsp). Civilian rates calculated by Army STARRS based on data from the Centers for Disease Control and Prevention's WISQARS data system (http://www.cdc.gov/injury/wisqars/index.html), adjusted to reflect the age, sex and race composition of the Army. 


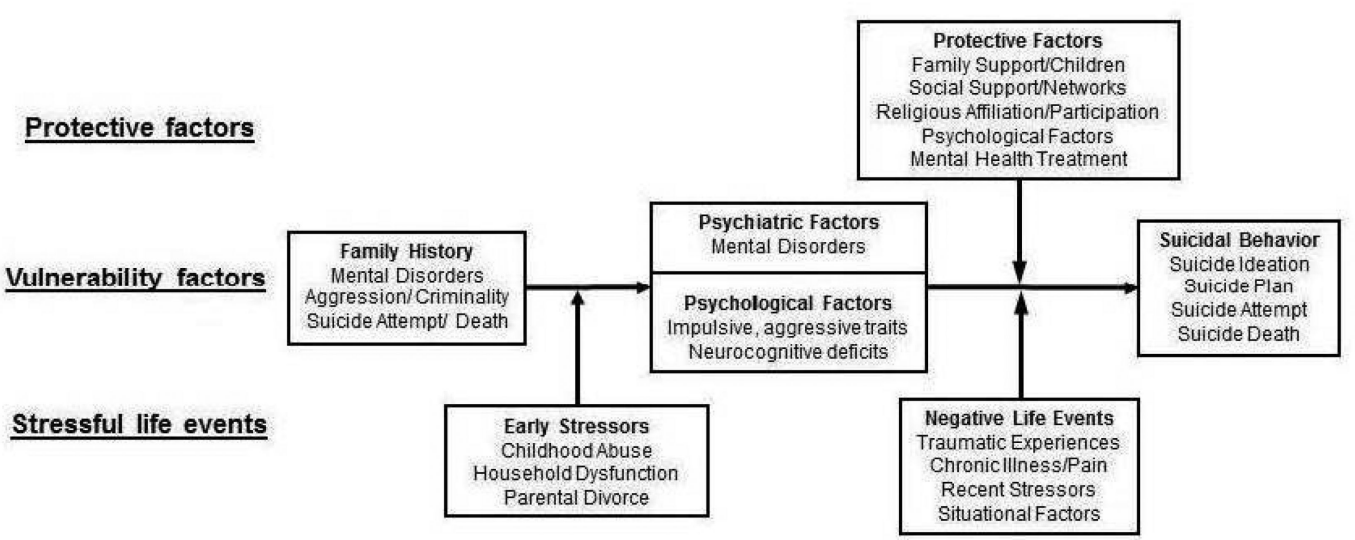

FIGURE 2.

Vulnerabilty-stress model of suicidal behavior. 


\section{TABLE 1}

\section{Key Directions for Future Research}

\begin{tabular}{|c|c|c|}
\hline Goal & Rationale & Strategy \\
\hline Description & $\begin{array}{l}\text { Knowledge of when, where, and among whom } \\
\text { suicidal thoughts and behaviors occur is essential to } \\
\text { understanding why these dangerous behaviors occur }\end{array}$ & $\begin{array}{l}\text { Monitor suicidal thoughts and behaviors among soldiers across time, } \\
\text { place, and person } \\
\text { Use the information gained to tailor assessment, screening, and } \\
\text { prevention efforts }\end{array}$ \\
\hline Prediction & $\begin{array}{l}\text { Suicide prevention is not possible without methods of } \\
\text { accurately identifying those at the highest risk for } \\
\text { such behavior }\end{array}$ & $\begin{array}{l}\text { Develop methods of predicting suicidal behavior with high } \\
\text { sensitivity and specificity } \\
\text { Prediction methods must be feasibly adapted across multiple } \\
\text { military contexts and must identify modifiable risk factors }\end{array}$ \\
\hline Protection & $\begin{array}{l}\text { The identification of modifiable protective factors for } \\
\text { suicide can guide prevention efforts }\end{array}$ & $\begin{array}{l}\text { Identify protective factors for suicidal behavior } \\
\text { Create prevention programs that train soldiers to develop these } \\
\text { factors } \\
\text { Test the effectiveness of such programs, and if effective, } \\
\text { disseminate to all soldiers }\end{array}$ \\
\hline Exploration & $\begin{array}{l}\text { Given the poor predictive ability of current risk } \\
\text { factors, it is likely that many risk factors are } \\
\text { unknown, highlighting the need for exploratory } \\
\text { studies of new risk factors }\end{array}$ & $\begin{array}{l}\text { Examine the predictive ability of a wide range of constructs and } \\
\text { variables not previously linked with suicide } \\
\text { Replicate effects of any novel risk factors that are discovered }\end{array}$ \\
\hline Understanding & $\begin{array}{l}\text { The development and evaluation of theoretical } \\
\text { models that explain how and why different factors } \\
\text { work together to produce suicidal behavior are needed } \\
\text { to advance scientific and clinical efforts }\end{array}$ & $\begin{array}{l}\text { Studies of suicide should carefully consider how each risk factor is } \\
\text { proposed to lead to suicide (e.g., what are mediators and } \\
\text { moderators?) and should test such relations } \\
\text { As understanding increases, results obtained must be fed into } \\
\text { screening and prevention efforts }\end{array}$ \\
\hline
\end{tabular}

